\title{
Materyalist Eğilim ve Tüketici Ahlakının Gösterişçi Tüketim Eğilimi Üzerindeki Etkisi
}

\section{Arş. Gör. Gizem Tokmak ${ }^{1 *}$}

Gelis tarihi: 03.10.2019

Kabul tarihi: 31.10 .2019

\section{Atıf bilgisi: \\ IBAD Sosyal Bilimler Dergisi \\ Sayl: $5 \quad$ Sayfa: $359-378$ \\ Yıl: 2019 Dönem: Güz}

This article was checked by iThenticate. Similarity Index 9\%

1 Bülent Ecevit Üniversitesi, Türkiye, gizem.tokmak89@hotmail.com,

ORCID ID 0000-0002-5855-6728

* Sorumlu yazar
ÖZ

Günümüzde çoğu insan için ürün satın almanın ardında yatan temel sebep, ürünün birincil faydasını ifade eden rasyonel temelden uzaklaşmış durumdadır. İnsanlar genellikle sosyal onay almak, statülerini göstermek, başkaları tarafindan takdir edilmek vb. sebepleri barındıran ikincil fayda için ürün satın alma davranışı göstermektedir. Ürünün rasyonel faydasını yok sayıp ikincil faydasına yönelik yapılan tüketim, gösterişçi tüketim olarak isimlendirilmektedir. Bu çalışmada gösteriş̧̧i tüketim eğilimi üzerinde materyalist eğilim ve ahlaki tüketim eğilimi ile birlikte demografik değişkenlerden cinsiyet ve aylık harcama miktarının anlamlı bir etkisi olup olmadığının tespit edilmesi amaçlanmıștır. Bu amaçla bir devlet üniversitesinin İ.İB.F.'nde okumakta olan 200 kadın ve 200 erkek öğrenci kolayda örnekleme yöntemiyle belirlenmiş ve veri toplama yöntemi olarak anket yöntemi uygulanmıştır. Çalışma 2018 bahar döneminde yapılmış ve very toplama süreci 3 ayda tamamlanmıştır. Elde edilen verilere yapılan çoklu doğrusal regresyon analizi sonucunda, bahsi geçen değişkenlerin gösterişçi tüketim üzerinde anlamlı etkisi olduğu; bağımsız örneklem $\mathrm{t}$ testi sonucunda ise kadınlar ve erkekler arasında gösterişçi tüketim eğilimi açısından anlamlı bir farklılık olduğu tespit edilmiştir.

Anahtar Kelimeler: Gösterişçi Tüketim, Materyalist Eğilim, Tüketici Ahlakı 


\section{Effects of Materialistic Tendency and Ethical Consumerism on Conspicuous Consumption Tendency}

\section{Res. Asst. Gizem Tokmak ${ }^{1 *}$}

First received: 03.10.2019

Accepted: 31.10.2019

\section{Citation:}

IBAD Journal of Social Sciences

Issue: 5

Pages: $359-378$

Year: 2019

Session: Fall

This article was checked by iThenticate. Similarity Index 9\%

1 Bülent Ecevit University, Turkey, gizem.tokmak89@hotmail.com,

ORCID ID 0000-0002-5855-6728

* Corresponding Author 


\section{GİRİŞ}

Neoklasik tüketim teorisi, kişilerin tüketim tercihlerinde tam anlamıyla rasyonel davrandıklarını belirtmektedir. Bu teoriye göre tüketimin ardında yatan temel motivasyonların sinırları bellidir, tüketim sosyal etkileşim, kültür ve/veya arkadaş çevresi gibi sosyal gruplarla olan etkileşim sonucunda oluşan doyumsuz hazlara bağlı değildir. Tüketim tercihlerinin ardında yatan sebepler fiyatla, gelirle ve kişisel zevklerle sinırlıdır (Hayakawa ve Venieris, 1977; Ackerman, 1997). Tüketim tercihlerinin ardında yatan sebepleri fiyat, gelir ve kişisel zevkler gibi rasyonel unsurlarla sınırlayan neoklasik tüketim teorisine farklı bir perspektiften bakan Veblen (1899), neoklasik tüketim teorisi varsayımlarını gösterişçi tüketim teorisiyle eleştirmiştir (Atik ve Şahin, 2011).

Veblen'in gösteriş̧̧i tüketim teorisi, neoklasikçi görüşün savunmuş olduğu, insanların ekonomik açıdan rasyonel oldukları varsayımını reddetmektedir. Çünkü insanlar sadece gelirlerine ve fiyata göre değil, sosyal statüye göre zenginliklerini gösterme amaçlı veya zengin olmasalar dahi "zenginmiş gibi görünmek" amaçlı harcamalar yapabilirler ve bu durum rasyonelliğe tam anlamıyla zıttır. Zenginlik göstermek veya zenginmiş gibi görünmek için yapılan harcamalar, malın irrasyonel olan ikincil faydası içindir. Veblen, malın birincil ve ikincil faydalarının olduğundan bahsederken ikincil faydaya yönelik yapılan harcamaları, insanların göreceli alım gücünün toplumdaki bir ispatı olarak değerlendirir. İnsanların sosyal bir varlık olduğu düşünüldüğünde ise onların tüketmeye karar verirken sadece birincil faydayı değil, ikincil faydası olan sosyal faydayı da göz önünde bulundurdukları ortaya çıkmaktadır (Açıkalın ve Erdoğan, 2004).

Veblen'e göre tüketim birincil faydadan çıkıp ileri bir noktaya gittiğinde toplumsal bir soruna dönüşebilmektedir. Bireysel tatminin toplumsal bir statü arayışına dönüşmesi, zenginliğin toplum yararına kullanılmak yerine israfa yönlendirilmesi ve bu durumun da herkes tarafindan taklit edilmesi Veblen'in tüketimin geldiği noktada eleştirdiği unsurlardandır (Güleç, 2015).

Bireylerin tüketimin birincil faydası yerine ikincil faydasına daha çok önem vererek gösterişçi tüketime yönelmelerinin sebebi olarak literatürde sıklıkla materyalist eğilimler gösterilmektedir. $\mathrm{Bu}$ çalışmada materyalist eğilimlerin yanı sıra gösterişçi tüketimle pek sık bağdaştırılmayan tüketici ahlakı kapsamında değerlendirilen ahlaki tüketim eğilimi, cinsiyet ve aylık harcama miktarı değişkenlerinin de gösterişçi tüketim üzerinde bir etkisi olup olmadığının tespit edilmesi amaçlanmıştır. Çalışmanın, cinsiyet ve ahlaki tüketim ile gösterişçi tüketim arasındaki ilişkiyi inceleyen çalışmaların oldukça sınırlı sayıda olması sebebiyle, literatürde bu alandaki boşluğu doldurmaya yardımcı olması beklenmektedir.

\section{KAVRAMSAL ÇERÇEVE}

\subsection{Gösterişçi Tüketim}

Gösterişçi tüketim, ürünün ekonomik ve psikolojik faydasından ziyade, sosyal faydasına daha çok eğilimli olma durumudur. Gösterişçi tüketimin temel motivasyonu, gösteriş yapmak için satın alma kararı vermektir. Bu sebeple gösterişçi tüketim, genellikle statü sembolü olan ürünlerle ilişkilidir (Mason, 1981).

Gösterişçi tüketim yapanlar, etraflarındaki diğer insanları etkilemek için sahip oldukları varlıkları kullanan ve bu nedenle daha çok ürüne/mala sahip olmak isteyen kişilerdir. Çünkü gösterişçi tüketim yapan insanlar için sahip oldukları varlıklara diğer insanların gösterdikleri tepkiler, onların temel motivasyonu olmaktadır. Gösteriş̧̧i tüketim yapanlar bu nedenle sahip oldukları maddi varlıklara çok değer verip bu varlıkları hayatlarındaki tek memnuniyet kaynakları olarak görmektedirler (Othman, 1989).

Gösterişçi tüketim kavramına literatürde ilk değinen kişi olan Veblen (1899) için gösterişçi tüketim, üst sosyal sınıf ve bu sınıflara benzemeye çalışan diğer sınıf üyeleri tarafından gösteriş amaçlı yapılan alışverişler olarak tanımlanmıştır. Veblen'in tanımladı̆̆ 1 doğrultuda, kişinin toplumdaki prestijini artırmak için toplum içinde tüketilen mal ve hizmetleri satın alması, bu mal ve hizmetleri diğer insanları etkilemek ve egosunu tatmin etmek için kullanması olarak tanımlanan gösterişçi tüketimin (O'Cass ve McEwen, 2005) statü tüketimi ile karıştırılmaması gerekmektedir. Statü tüketimi kişilerin statü sembolü olan ürünleri çevrelerindeki kişilere statülerini göstermek amacı ile satın almalarına neden olan 
motivasyonel bir süreç olarak tanımlanmaktadır (Eastman vd., 1999). Her ne kadar bu yönüyle gösterişçi tüketime benzese de statü tüketiminde satın alınan ürünlerin pahalı olmasına gerek yoktur. Bu yönüyle statü tüketimi, gösterişçi tüketimden ayrılmaktadır.

Gösterişçi tüketim literatürde genellikle materyalist eğilimlerle ilişkilendirilmektedir. Gösterişçi tüketim, yüksek seviyede materyalizmin bir tezahürü olarak düşünülmektedir. Belk (1983)'e göre gösterişçi tüketim, tüketici davranışlarındaki gösterişin materyalist yönünün öne çıkan bir göstergesidir. Gösterişçi tüketim, bir kişinin sahip olduklarına etrafındaki kişilerin gösterdiği tepkilerden duyduğu memnuniyette ortaya çıkmaktadır. Gösterişçi tüketim yapan bir kişi bu sebeple sahip olduğu maddi varlıkları mutluluğunun kaynağı olarak görmektedir. Materyalist eğilimleri yüksek olanların düşük olanlara göre gösterişçi tüketime daha çok eğilimli oldukları düşünülmektedir. Materyalist eğilimleri düşük olanlar paranın her şey olmadığına inanmakta ve her zaman mutluluk getirmediğini düşünmektedir. Bu sebeple, materyalist eğilimi düşük olanların gösterişçi tüketimden uzak duracakları düşünülmektedir (Othman, 1989).

\subsection{Gösteriş̧̧i Tüketim Eğiliminin Ölçümü}

Tüketici davranışları literatüründe gösterişçi tüketim kavramı yapısal olarak nispeten daha az çalışılmış durumdadır. Bu kavramı ilk olarak Porter (1967) ölçmeye çalışmış ve katılımcılardan 30'dan fazla maddi varlık üzerinden birtakım soruları cevaplamaları istenmiştir. Yapmış olduğu analiz sonucunda katılımcıların yıllık ev, kalacak yer, kıyafet, başkalarına alınan hediye vb. harcama oranlarının sorulduğu bir ölçek geliştirilmiştir; fakat Porter (1967) çalışmasında, gösterişçi tüketimi aşırı tüketimle eş tutması noktasında eleştirilmiştir. Aşırı tüketim yapan kişi, bu tüketimi birilerine gösterme amacıyla yaptığında gösterişçi tüketim yapmış olmaktadır; fakat Porter (1967) çalışmasında bu detayı göz önünde bulundurmamıştır. Gösterişçi tüketimi ölçmek için Moschis (1981) ile Lumpkin ve Darden (1982) tarafından geliştirilen ölçekler de mevcuttur. Moschis (1981) tarafından geliştirilen ölçek, kişinin tüketimdeki sosyal motivasyonunu ölçerken Lumpkin ve Darden (1982) tarafindan geliştirilen ölçek kişinin moda bilincini ölçmektedir. Moschis (1981) tarafından geliştirilen tüketim motivasyonu ölçeği 4 boyutludur. Lumpkin ve Darden (1982) tarafından geliştirilen moda bilinci ölçeği ise 2 boyutludur.

Othman (1989) tarafindan geliştirilen ve bu çalışmada kullanılan ölçek ise 10 maddeden oluşmaktadır. $\mathrm{Bu}$ ölçek tüketicilerin gösterişçi tüketim eğilimi ve gösterişçi tüketime olan tutumu olmak üzere iki boyutu ölçmektedir. Ölçekteki maddelerden biri (3. Madde) tüketicinin, ürünün sosyal görünürlüğü hususundaki tutumunu, ölçekteki 3 madde (4., 6. ve 8. Maddeler) tüketicinin, ürünün sosyal kabulü hususundaki tutumunu, ölçekteki 4 madde (1.,2.,5.,7. ve 9. Maddeler) tüketicinin, ürünün statü göstergesi olma durumuna olan tutumunu, 1 madde ise (10. Madde) ürünün tüketiciye getirdiği imaj1 ölçmektedir.

Gösterişçi tüketim ile materyalist eğilimler arasındaki ilişkinin yüksek olması beklenmektedir. Belk (1983) ve Veblen (1899) gösterişçi tüketimin, materyalizmin en önemli öncüllerinden biri olduğu görüşündedir.

\subsection{Materyalist Ĕgilim}

Materyalizm kavramı ilk olarak Ward ve Wackman (1971) tarafindan, bireylerin para ve maddi varlıkları, kişisel mutluluk ve sosyal ilerleyişlerine giden bir yol olarak görmesi şeklinde tanımlanmıştır. Pazarlama alanında materyalist eğilim konusunda en çok çalışma yapan araştırmacılardan biri olan Belk (1987) ise materyalizmi, ürünlerin ve hizmetlerin hayattaki memnuniyet ve memnuniyetsizliğin en büyük kaynağı olduğuna inanma eğilimi olarak tanımlamıştır. Belk’e göre materyalist eğilimli kişiler sahip oldukları ya da olamadıkları varlıkları yaşamlarının merkezi haline getirmekte ve yaşamlarındaki tatmin ya da tatminsizliğin en büyük nedeni olarak söz konusu bu varlıkları göstermektedir (Parker vd., 2009; Christopher vd., 2004). Richins (1987) ise materyalizmi sahip olunanlarl, hayattan duyulan memnuniyet noktasında önemli bir kaynak olarak görme eğilimi olarak tanımlarken Belk ve Pollay (1985) materyalizmi, tüketimi mutluluğa, anlama ve pek çok kişisel problemi çözmede önemli bir yol olarak görme eğilimi olarak tanımlamaktadır.

Materyalist eğilimleri yüksek olan bireyler, ürünlerden sağlanan sosyal ve psikolojik faydalarla ilgili gerçekçi olmayan beklentiler içine girerler ve satın alma sonrası bir şeylere sahip olma mutluluğunu çabucak unutup daha fazlasını istemeye başlarlar (Richins ve Dawson, 1992). Materyalist eğilimli 
bireylerin pek çoğu, kendilerinin ya da başkalarının başarılarını, sahip oldukları mal ve paraya göre değerlendirirler. Arzuladıkları imajı yansıtan özelliklere sahip ürünleri elde ettikçe kendilerini başarılı addeden bu bireyler için sahip olduklarının maliyeti, sağladıkları tatminden daha önemlidir. Yani maddi varlık sahipliği, onlar için başarının en önemli göstergesidir (Ashlay vd., 2013). Her ne kadar maddi varlık sahipliği, materyalizmde önemli bir nokta olsa da bir insanın ne derece materyalist olduğu, sahip olduğu gelir seviyesiyle ilişkili olmak zorunda değildir. Örneğin oldukça varlıklı olan fakat sahip olduğu maddi varlıklara çok da bağlı olmayan biri materyalist bir birey olarak düşünülemez. Öte yandan neredeyse hiçbir şeyi olmayan ve fakat sahip olduğu veya olmadığı maddi varlıklara oldukça bağlı olan biri ise materyalist olarak değerlendirilebilir (Othman, 1989).

Materyalist eğilimli bireyler, sahip oldukları ya da sahip olmayı istedikleri mal ve mülkleri yaşam amaçları haline getirmektedirler. Onlara göre materyalizm bir yaşam tarzıdır ve bu yaşamda yüksek düzeyde maddi tüketimler araçtan öte amaçtır. Bu noktada araçsal ve amaçsal materyalizm kavramları önem kazanmaktadır. Amaçsal materyalizm, ürün ve hizmetlerin sahipliği ve tüketimi, sonuca götüren bir yol olmaktan ziyade sonucun kendisi olduğunda ortaya çıkmaktadır. Örneğin tüketmek adına tüketim, amaçsal materyalizmin bir yansımasıdır. Buna karşın araçsal materyalizm, birtakım amaçları keşfetmek ve bunlara ulaşmak için sahip olunan ürün ve hizmetleri bir yol olarak görmektir. Bu nedenle araçsal materyalizmde sahip olunan varlıklar, amaçlara ulaşmak için sadece birer araç olmaktadır (Csikszentmihalyi ve Rochberg-Halton, 1981).

\subsection{Materyalist Eğilimlerin Ölçümü}

Materyalizm yapısının ölçümüyle ilgili olarak yapılan çalışmalar, materyalizmin tek boyutlu veya çok boyutlu yapıya sahip olduğu düşüncesinden yola çıkılarak yapılmıştır. Konuyla ilgili ilk yaklaşım materyalizmin çok boyutlu bir yapısı olduğunu iddia etmektedir. Belk (1985) yapmış olduğu çalışmasında bu yaklaşımı desteklemiş ve sahipliğin, cömert olmamanın ve kıskançlığın, materyalizm ile ilişkili olduğunu öne sürmüştür. Materyalist eğilim skorunu, bu üç boyutun skor toplamının bir sonucu olarak değerlendirmiştir. Konuyla ilgili olan bir diğer yaklaşım ise materyalizmin tek boyutlu bir yapıya sahip olduğunu ileri sürmüştür. Bu yaklaşım altında, biri Ward ve Wackman (1971) bir diğeri de Richins (1987) tarafindan iki ölçek geliştirilmiştir. Ward ve Wackman (1971)'ın ölçeği, tüketici davranışları literatüründe materyalist eğilimlerin ölçümünde kullanılan ilk ölçektir. Richins (1987)'in materyalizm ölçeğinde ise sahip olunan her bir maddi varlık, hayattaki kişisel mutluluk ve memnuniyetle ilişkilendirilmiştir. Richins söz konusu ölçeğe temel bileşenler analizi yaptıktan sonra ölçeğin tek boyutlu olmadığına, kişisel materyalizm ve genel materyalizm olmak üzere iki boyutlu olduğuna karar vermiştir. Ölçekteki kişisel materyalizm, kişinin daha çok sahip oldukça daha mutlu olacağına olan inancın derecesiyken genel materyalizm, paranın mutluluk getirdiğine olan genel inancı ifade etmektedir. Söz konusu üç materyalizm ölçeği karşılaştırıldığında Richins (1987)'in materyalizm ölçeğinin, geçerlilik açısından daha güçlü bir ölçek olduğu kabul edilmektedir (Othman, 1989).

Materyalist eğilimlerin ölçülmesi amacıyla geliştirilen bir diğer ölçek ise Richins ve Dawson (1992) tarafından geliştirilen Maddi Değerler ölçeğidir. 18 maddeden oluşan bu ölçekte kişilerin sahip oldukları maddi varlıkları başarı göstergesi olarak görüp görmediklerini, hayatlarının merkezine koyup koymadıklarını ve hayattaki mutluluklarının kaynăg 1 olarak görüp görmediklerini ölçen sorular yer almaktadır. Bu çalışmada da tüketicilerin materyalist eğilimlerinin tespiti için, araştırma konusuyla diğer ölçeklere göre daha ilişkili olduğu düşünülen Richins ve Dawson (1992) tarafindan geliştirilen Maddi Değerler ölçeği kullanılmıştır.

Literatürde yapılmış olan çalışmalar, materyalizmin gösterişçi tüketim ile ilişkili olduğu kadar ahlaki tüketimle/tüketici ahlakıyla da ilişkili olduğunu göstermiştir. Bu çalışmanın bağımsız değişkenlerinden biri olan tüketici ahlakının/ahlaki tüketimin bu noktada açıklanması uygun görülmektedir.

\subsection{Tüketici Ahlakı}

Pazarlamada tüketici ahlakı ya da ahlaki tüketim, tüketicilerin ahlaki standartları karşılayan ürünleri satın alıp ahlaki standartlar dışında kalan ürünleri bilinçli olarak satın almama eğilimleri konusunu kapsamaktadır. Buradaki "ahlaki olma" kavramı çevreye duyarlılıkla ilgili olduğu kadar hayvan hakları, adil ticaret, işçi hakları ve organik gida satışı gibi sağlık konularını içeren sosyal yönlere olan duyarlıl1kla da ilgilidir (Cho ve Krasser, 2011). 
Tüketici ahlakına sahip bir tüketicinin bilinçli bir şekilde kendi ahlakına ve değerlerine uygun olan ürünleri tercih etmesi beklenmektedir. Bu kavram, yeşil tüketim ve çevreyi korumaya yönelik eylemlerden ortaya çıkmıştır. Yeşil tüketim genel anlamda, çevreyi koruma ve organik üretim gibi çevresel kaygılara bağlı olarak tüketim tercihi yapmaktır. Buna karşın tüketici ahlakı ise daha karmaşık bir yapıdadır. Tüketici ahlakının üç farklı türü bulunmaktadır. Bunlar boykot, buycott ve söylemsel ahlaki tüketimdir. Boykot genel anlamda ahlaki ve sosyal standartları karşılamayan ürünleri satın almayı reddetmek olarak tanımlanırken buykott ise bu standartları karşılayan ürünleri satın alma eylemi olarak tanımlanmaktadır. Söylemsel ahlaki tüketim ise belli başlı ürünleri satın almak ya da almamakla ilgili değildir, daha çok şirket imajı, marka adı, şirketin itibarı ve logosu gibi diğer hassas konuları hedef almaktadır. Ahlaki standartlara uygun üretim yapmayan şirketler hakkında lobi yapmak vb. eylemleri içermektedir (Cho ve Krasser, 2011).

Tüketiciler dünya genelinde gün geçtikçe sosyal ve ahlaki konulara karşı daha bilinçli hale gelmektedir. Tüketiciler artan bir şekilde enerji tasarruflu ürünleri, organik gıdayı ve adil bir şekilde işçi çalıştıran markaların ürünlerini satın alarak ve kötü çalışma şartları barındıran markaların ürünleri ile hayvan haklarını ihlal edecek şekilde üretilen ürünleri satın almayarak hem çevresel hem de sosyal sorumluluklarını göstermektedir (Cho ve Krasser, 2011). Literatürde tüketici ahlakı kapsamı altında sayılan bu eylemler ürünlerin ve hizmetlerin satın alınması ve elden çıarılması süreçlerinde kişilerin ve grupların davranışlarını yönlendiren ahlaki prensipler ve standartlardır (Muncy ve Vitell, 1992). Tüketici ahlakı tüketicilerin ürün ve hizmetleri satın alma, kullanma ve elden çıkarma gibi tüketim alışkanlıklarında kendini göstermektedir. Ahlaki tüketim, kişinin kendi özgür iradesiyle seçtiği ürün ve hizmetlerin satın alınması ve kullanılması sürecinde insan hakları, işçi koşulları, hayvan hakları ve çevreyi koruma gibi ahlaki konulara önem vermesidir (De Pelsmacker vd., 2005). Ahlaki tüketimin bazı formları çevreyi koruma ve geliştirme konusunda katkı sağlarken bazıları insan hayatına katkı sağlamaktadır.

Ahlaki tüketim eylemi ardında birtakım sebepler bulunabilmektedir. Örneğin ahlaki tüketim eylemlerinden biri olan çevre dostu yeşil ürünlerin satın alınmasının ardında gösterişçi tüketim eğilimi olabilmektedir. Şöyle ki kişi etrafındaki insanlara çevre dostu markaları kullandığını gösterme güdüsüyle ahlaki tüketim eylemi sergileyebilmektedir. Böylece sosyal kabul alan kişi, ahlaki tüketim eyleminden kişisel bir fayda sağlamış olmaktadır (Cho ve Krasser, 2011). Bu sebeple gösterişçi tüketim ve ahlaki tüketim arasında bir ilişkiden söz edilebilmektedir. Literatürde tüketici tutarsızlığ olarak da isimlendirilen (De Pelsmacker vd., 2005) bu satın alma davranışında kişi gerçek niyetine göre değil de sosyal kabul alacağı şekilde ve toplumda iyi bir imaj çizmek amacıyla ahlaki tüketim davranışı göstermektedir.

Ahlaki tüketim, materyalizm ve post materyalizm ile de ilişkilidir. Materyalizm, kişinin sahip olduğu maddi varlıklara verdiği önem ile ilgiliyken post materyalizm çevre koruma, insan hakları, sürdürülebilir kalkınma, hayat kalitesi vb. konulara verdiği önemle ilgilidir. Bununla birlikte post materyalizm antimateryalizm demek değildir. Yapılan çalışmalar ahlaki tüketimin materyalizm ve boykot ile negatif yönde ilişkili olduğunu göstermektedir. Buna karşın post materyalizm ile ahlaki tüketim arasında pozitif yönde ilişki olduğu düşünülmektedir (Cho ve Krasser, 2011).

\subsection{Tüketici Ahlakının Ölçümü}

Çalışmada katılımcıların ahlaki tüketim eğilimini ölçmek amacıyla Munchy ve Vitell (1992) tarafindan geliştirilen tüketici ahlakı ölçeği kullanılmışır. Bu ölçekte tüketicilere bazı ifadeler yöneltilmiş ve tüketicilerden bu ifadelerin ne kadar ahlaki olup olmadığını Likert ölçeğiyle değerlendirmeleri istenmiştir. Literatürde ahlaki tüketim genellikle içerisinde "çevreye duyarlı satın alma davranışı" nı ölçen ifadelerle ölçülmektedir. Bu çalışmanın örneklemi öğrencilerden oluştuğundan ve öğrencilerin gelirlerinin, diğer ürünlerden daha pahalı olabilen yeşil ürünleri satın almaya yetmeyebileceğinden, örneklem özelliklerine daha uygun olduğu için söz konusu ölçek tercih edilmiştir.

\section{LITERATÜR TARAMASI}

Çoğu araştırmacı gösterişçi tüketim eğiliminin, materyalizmin göstergesi olduğu görüşündedir (Dawson ve Cavell, 1987; Belk, 1983; Belk, 1985). Materyalizm ile gösterişçi tüketim arasındaki ilişkiyi incelediği çalışmasında Belk (1986), meslek sahibi olan, hırslı ve maddi şeylere çok fazla önem veren 
genç kesimin gösterişçi tüketimi pozitif bir şekilde değerlendirdiklerini ve onu yaşam tarzları haline getirdiklerini tespit etmiştir. Veblen (1899)'in, üniversitedeki akademik personellerin gösterişçi tüketime daha eğilimli olduğu görüşünü test etmek amaciyla çalışma yapan Porter (1987), çalışmasında akademik personeller ile iş adamlarını gösterişçi tüketim eğilimleri açısından karşılaş̧ırmış ve iş adamlarının akademik personellere göre gösterişçi tüketime daha eğilimli olduklarını tespit etmiştir. Othman (1989) materyalizm ile gösterişçi tüketim arasındaki ilişkiyi araştırdığı çalışmasında materyalizm eğilimi yüksek olan kişilerin gösterişçi tüketim eğilimlerinin, materyalizm eğilimi düşük olan kişilere göre daha yüksek olduğunu tespit etmiştir. Aslay vd. (2013) materyalizmin, gösteriş̧̧i tüketimin bir diğer yansıması olan statü tüketimi üzerindeki etkisini araştırdıkları çalışmalarında statü göstergesi olarak düşünülen plazma/LCD televizyon sahibi kişiler üzerinde anket uygulaması gerçekleştirmiştir. Çalışma sonucunda statü tüketiminin materyalist eğilimi yüksek kişilerde daha fazla olduğunu, materyalist eğilimi yüksek kişilerin sadelikten kaçınma eğilimlerinin daha yüksek olduğu ve maddi varlıklara sahip olmaktan daha mutlu oldukları tespit edilmiştir. Barzoki vd. (2014) gösterişçi tüketim ve materyalizm arasındaki olası ilişkiyi 362 genç kadın üzerinden araştırdıkları çalışmalarında gösterişçi tüketimin materyalizmle istatistiksel olarak anlamlı bir şekilde ilişkili olduğunu tespit etmiştir. Lee vd. (2015) lüks ve lüks olmayan marka logolarının sosyal faydası ve statü algısı üzerine yapmış oldukları çalışmalarında insanların kurmuş oldukları sosyal ilişkileri, kullandıkları markaların lüks olup olmamasının etkilediğini tespit etmiştir. Araştırmada ayrıca, lüks marka kullananların lüks marka kullanmayanlara göre daha ayrıcalıklı muamele gördüğü tespit edilmiştir.

Tüketici ahlakı kavramı, bu çalışmada üzerinde çalışılan bir diğer konudur. Vitell vd. (1991) yapmış oldukları çalışmada yaşı büyük tüketicilerin genç tüketicilere göre ahlaki tüketim eğilimlerinin daha yüksek olduğunu tespit etmiştir. Kilbourne ve Pickett (2008) materyalizm ve ahlaki tüketim arasındaki ilişkiyi araştırdığı çalışmasında materyalizmin ahlaki tüketim davranışlarından biri olan çevreye duyarlı tüketim üzerinde negatif yönde etkisi olduğunu tespit etmiştir. Cho ve Krasser (2011) Avusturyalı ve Güney Koreli tüketiciler üzerinden tüketicilerin ahlaki tüketim eğilimlerinin ardında yatan sebepleri ve kültürel unsurların ahlaki tüketim eğilimi üzerindeki etkisini araştırdıkları çalışmalarında materyalist eğilimleri kültürel faktörler altında değerlendirerek incelemişlerdir. Araştırma sonuçları Avusturyalı tüketicilerin ahlaki tüketim eğilimlerinin, Güney Koreli tüketicilerden daha yüksek olduğunu göstermiştir. Buna ilaveten materyalist eğilimler de ahlaki tüketimin önemli bir tahmin edicisi olarak tespit edilmiştir. Znidersic vd. (2013) ahlaki tüketim konusunda yapmış oldukları çalışmalarında katılımcıların ahlaki tüketim eğilimleri, ahlaki tüketim davranışlarını ne sıklıkla yaptıkları ölçülerek değerlendirilmiştir. Çalışma sonucunda katılımcıların büyük bir yüzdesinin kendini ahlaki tüketim yapan bireyler olarak değerlendirirken (\%32), büyük bir kısmının kendini tam anlamıyla ahlaki tüketim yapan birey olarak değerlendirmedikleri (\%37) tespit edilmiştir. Buna ilaveten katılımcıların \%60'ının ahlaki tüketimin çevre ve ülke için son derece önemli olduğunu düşündükleri tespit edilmiştir.

Gösterişçi tüketim ile ahlaki tüketim arasındaki ilişkiyi doğrudan inceleyen çalışmalar literatürde sınırlı sayıdadır. Ahlaki tüketim literatürde genellikle materyalist eğilimler ile ilişkilendirilmiştir. Gösterişçi tüketim ve ahlaki tüketim eğilimi arasındaki ilişkileri inceleyen çalışmalar, Masraflı Sinyalleşme Teorisi altında bu ilişkiyi açıklamaya çalışmışlardır. Masraflı sinyalleşme teorisine göre herkesin kolaylıkla satın alamayacağı pahalı yeşil ürünleri satın almak gibi ahlaki tüketim pratikleri ile kişi, varlıklı olduğuna dair sinyaller yollamak amacıyla bu tür eğilimler içine girmektedir. Özellikle herkes tarafindan rahatlıkla görülebileceği ortamlarda alışveriş yapan kişi, yeterli para, enerji ve zaman gibi statü unsurlarına sahip olduğunun sinyalini verebilmek için diğerlerinden daha pahalı olan "yeşil" ürün kategorisindeki ürünleri satın alma eğiliminde olabilmektedir. Böylece kişi, çevreye duyarlı olduğu için değil, statü sinyali verebilmek için ahlaki tüketim davranışları sergileyebilmektedir (Hardy \& Van Vudt, 2006; Zahavi ve Zahavi, 1997). Konuyla ilgili olarak, Griskevicius (2008) statü amaçlı tüketim ve ahlaki tüketimin bir örneği olan çevreye duyarlı satın alma davranışı arasındaki ilişkiyi incelediği doktora tez çalışmasında insanların başkalarının görebileceği mağaza vb. ortamlarda alışveriş yaparken statülerini gösterme kaygısı ile çevreye duyarlı satın alma eğilimlerinin daha yüksek olduğunu, özellikle bu ürünler diğer ürünlerden daha pahalı olduğunda bu tür satın alma eğilimlerinin daha yüksek olduğunu tespit etmiştir. Öte yandan insanların internet ortamı gibi kimsenin görmediği ortamlarda alışveriş yaparken, statülerini başkalarına gösterme kaygısı taşımayacakları için çevreye duyarlı satın alma eğilimlerinin düşük olduğunu tespit etmiştir. Hartman ve Ibanez (2012) tüketicilerin çevreye duyarlı satın alma 
davranışlarının ardındaki sebepleri araştırdıkları çalışmalarında tüketicilerin topluma kendini ifade etme/gösterişçi tüketim eğiliminin çevreye duyarlı satın alma davranışını pozitif yönde etkilemediğini tespit etmişlerdir. Araştırmacılar bu sonucun ortaya çıkmasını, çevreye zararı olmayan enerji kullanımı eğiliminin ölçülmesiyle ilişkilendirmişlerdir. Şöyle ki, bu tür çevre dostu ürünlerin satın alınması, herkesin görebileceği mağaza vb. ortamlarda yapılmadığından tüketicilerin gösteriş amaçlı tüketim eğilimleri bu tür ürünlerin satın alınması üzerinde etkili olmamışır. Bu açıdan düşünüldüğünde söz konusu araştırma sonuçları, Griskevicius (2008)'un araştırma sonuçları ile paralellik göstermiştir.

Literatürde yapılmış olan çalışmalar, gösterişçi tüketimin, masraflı sinyalleşme teorisi doğrultusunda tüketimin nerede yapıldığıyla ilgili olduğu kadar cinsiyet ile de ilişkili olduğunu göstermektedir. Griskevicius vd. (2007) yapmış oldukları çalışmada erkeklerin karşı cinsi etkilemek amaciyla lüks ürünleri gösterişçi bir biçimde kullanmaya daha eğilimli olduğu tespit edilmiştir. Sundie vd. (2011) ve Wang ve Griskevicius (2014) da yapmış oldukları çalışmalarında erkeklerin zenginlik, güç vb. sosyal statülerini karşı cinse mesaj vermek amacıyla gösterişçi bir biçimde kullanmaya daha eğilimli oldukları tespit edilmiştir. Aydın ve Karamehmet (2015) de yapmış oldukları çalışmalarında lüks tüketim ürünlerinin karşı cinsi etkilemek amacıyla kullanımın cinsiyete göre farklılaşıp farklılaşmadığını araştırmış ve erkeklerin kadınlara göre romantik güdülenme sonrasında gösteriş̧̧i tüketim ürünlerine daha fazla para harcama niyetlerinin olduğunu tespit etmiştir.

\section{TASARIM VE YÖNTEM}

$\mathrm{Bu}$ çalışmada tüketicilerin gösterişçi tüketim eğilimleri üzerinde cinsiyet, aylık harcama miktarı, materyalist eğilim ve ahlaki tüketim eğilimi değişkenlerinin istatistiksel olarak anlamlı bir etkisinin olup olmadığının tespit edilmesi amaçlanmıştır. Bu doğrultuda bir devlet üniversitesinin iktisadi ve idari bilimler fakültesinde okumakta olan 200 erkek ve 200 kadın öğrenci kolayda örnekleme yöntemi ile belirlenmiştir. Araştırmanın değişken sayısının 10 katı alınarak örneklem sayısı 400 olarak belirlenmiştir. Araştırma 2018 bahar döneminde yapılmış ve veri toplama süreci 3 ayda tamamlanmıştır. Yapılan literatür taraması sonucunda araştırmanın modeli ve hipotezleri kurulmuştur. Araştırmanın modeli Şekil 1'deki gibidir:

Şekil 1. Araştırmanın Modeli

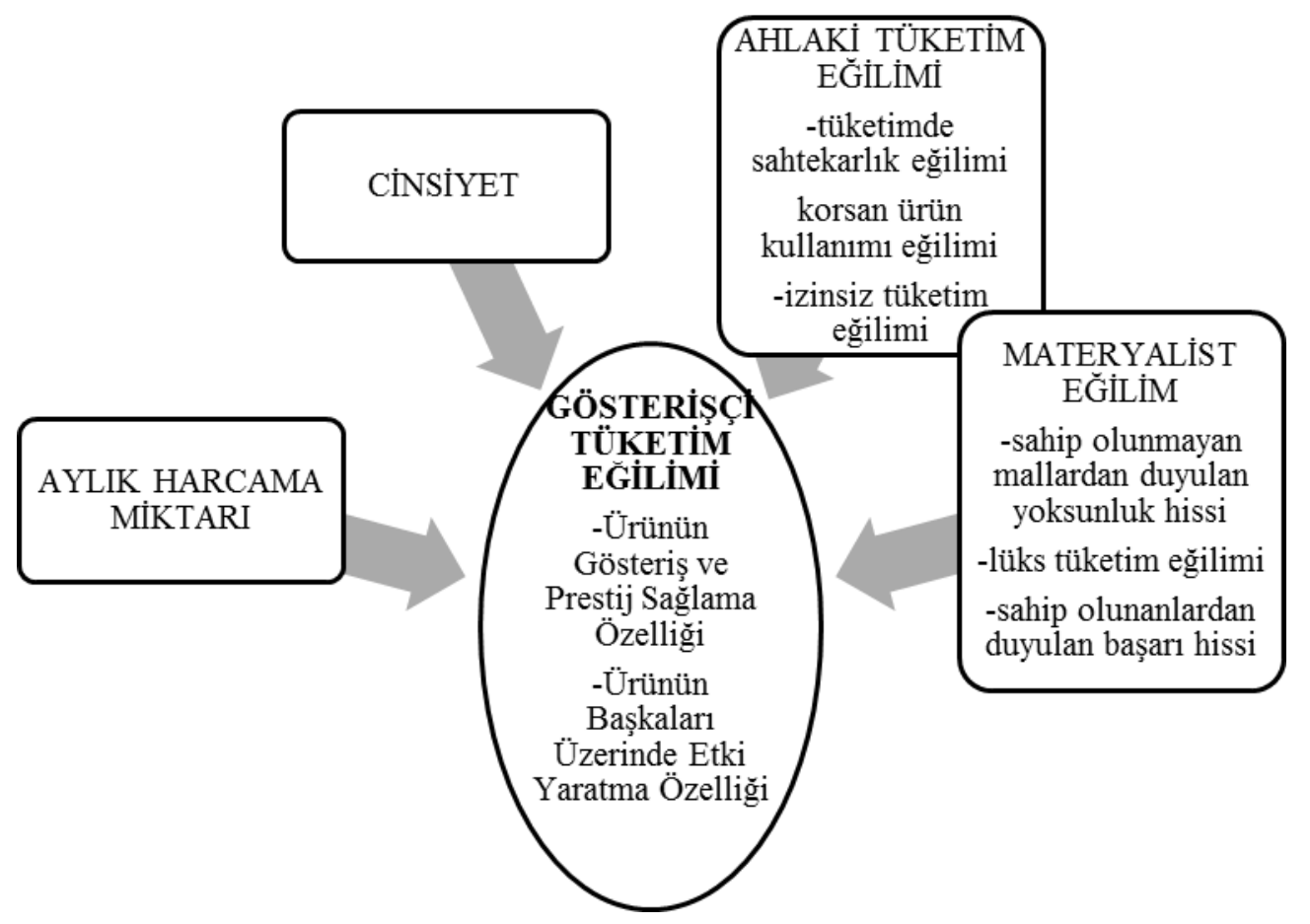


Araştırmanın ana hipotezleri şu şekilde kurulmuştur:

$\mathrm{H}_{1}$ : Ahlaki tüketim eğiliminin gösterişçi tüketim eğilimi üzerinde istatistiksel olarak anlamlı bir etkisi vardir.

$\mathrm{H}_{2}$ : Materyalist eğilimin gösterişçi tüketim eğilimi üzerinde istatistiksel olarak anlamlı bir etkisi vardır.

$\mathrm{H}_{3}$ : Aylık harcama miktarının gösterişçi tüketim üzerinde istatistiksel olarak anlamlı bir etkisi vardır.

$\mathrm{H}_{4}$ : Cinsiyet gösterişçi tüketim üzerinde istatistiksel olarak anlamlıbir farklılık oluşturmaktadır.

Çalışmanın bağımlı değişkeni olan gösterişçi tüketim eğilimi, Othman (1989) tarafindan geliştirilen ve 10 maddeden oluşan bir ölçek ile ölçülmüştür. Söz konusu ölçeğe öncelikle güvenilirlik analizi yapılmış ve bu analiz sonucunda ölçeğin 2. maddesinin, ölçekten çıkarılmasına karar verilmiştir. Bu işlem sonrasında yapılan güvenilirlik analizi sonucunda ölçeğin Cronbach's Alpha değeri, 0.703 olarak bulunmuştur. Bu değer, ölçeğin oldukça güvenilir olduğunu (Kalayc1, 2010:405) göstermekle birlikte tek başına yeterli bir ölçüt değildir. Güvenilirlik analizi sonucunda söz konusu ölçek açımlayıcı faktör analizine ${ }^{1}$ tabi tutulmuş ve faktör yükü \%50'nin altında olanlar ölçekten çıkarılmıştır. Bunun sebebi, faktör yükünün en az \%50 olması halinde faktörlerin toplam varyansın \%30'unu açıklayabildiği ve bunun istatistiksel olarak "iyi" bir şekilde değerlendirilmesidir (Tabachnick ve Fidell, 2001). Bu sonuçtan yola çıkılarak gösterişçi tüketim ölçeğinden 4. ve 10. maddelerin de çıkarılmasına karar verilmiş ve eldeki faktör yükü \%50'nin üzerinde olan 7 madde ile bağımlı değişken olarak çalışılmaya devam edilmiştir. Othman (1989)'a göre gösterişçi tüketim eğilimi ölçeğinin 1.,5.,7. ve 9. maddesi tüketicilerin ürünün statü göstergesi olma durumuna olan tutumunu, 3. maddesi ürünün sosyal görünürlüğüne olan tutumunu, 6 . ve 8 . maddeler ise tüketicinin ürünün sosyal kabulü hususundaki tutumunu ölçmektedir. Bu araştırmada ise 1., 3., 5. ve 7. maddelerin bir faktör, 6., 8. ve 9. maddelerin ise bir faktör altında toplandığı tespit edilmiştir. Aynı faktör altında toplanan maddelerin ortak temalarının belirlenmesi sonucunda birinci faktör "ürünün gösteriş ve prestij sağlama özelliği", ikinci faktör ise "ürünün başkaları üzerinde etki yaratma özelliği" olarak isimlendirilmiş ve modele de bu ifadeler yazılmıştır.

Çalışmanın bağımsız değişkenlerinden biri olan ahlaki tüketim eğilimi, Munchy ve Vitell (1992) tarafından geliştirilen Likert ölçekli tüketici ahlakı ölçeği kullanılarak ölçülmüştür. Söz konusu ölçeğe güvenilirlik analizi yapılmış ve Cronbach's Alpha değeri 0.867 olarak bulunmuştur. Bu sonuç, ölçeğin yüksek derecede güvenilir olduğunu göstermektedir (Kalaycı, 2010:405). Sonrasında yapılan açımlayıcı faktör analizi sonucunda söz konusu ölçek maddelerinin 3 faktör altında toplandığı tespit edilmiştir. Aynı faktörler altında yer alan maddelerin ortak teması incelendiğinde 1. faktörün "tüketimde sahtekarlık eğilimi”, 2. faktörün "korsan ürün kullanımı eğilimi”, 3. faktörün ise "izinsiz tüketim eğilimi” olarak isimlendirilmesine karar verilmiş ve modelde söz konusu değişken altında bu isimler belirtilmiştir.

Çalışmanın diğer bağımsız değiş̧keni olan materyalist eğilim ise Richins ve Dawson (1992) tarafindan geliştirilen Likert ölçekli Maddi Değerler ölçeği kullanılarak ölçülmüştür. Söz konusu ölçeğe güvenilirlik analizi yapılmış ve analiz sonucunda ölçekteki 10 maddenin çıkarılmasına karar verilmiştir. Sonrasında yapılan analiz sonucunda Cronbach's Alpha değeri 0.738 olarak bulunmuştur. Sonrasında yapılan faktör analizi sonucunda söz konusu ölçek maddelerinin 3 faktör altında toplandığı tespit edilmiştir. Aynı faktörler altında yer alan maddelerin ortak teması incelendiğinde 1. faktörün "sahip olunmayan mallardan duyulan yoksunluk hissi", 2. faktörün "lüks tüketim eğilimi”, 3. faktörün ise "sahip olunan maddi varlıklardan duyulan başarı hissi" olarak isimlendirilmesine karar verilmiş ve bu isimler modelde söz konusu değişken altında belirtilmiştir.

\section{BULGULAR}

$\mathrm{Bu}$ çalışmanın örneklemini 200 erkek ve 200 kadın olmak üzere toplam 400 lisans öğrencisi oluşturmaktadır. Katılımcıların yaş ortalaması 22 olarak bulunmuştur. Aylık ortalama harcama miktarı ise 768,21 TL olarak tespit edilmiştir.

\footnotetext{
${ }^{1}$ Sayfa düzeni nedeniyle ölçeklerin açımlayıcı faktör analizine ilişkin sonuçlar, EK 1'de gösterilmiştir.
} 
Çalışmanın bağımlı değişkeni ve bağımsız değișkenlerini ölçmek için kullanılan ölçeklerin ortalama ve standart sapma değerleri Tablo 1, Tablo 2 ve Tablo 3'te gösterilmektedir:

Tablo 1. Materyalist Eğilimler Ölçeği Ortalama ve Standart Sapma Değerleri (5'li Likert Ölçekli)

\begin{tabular}{l|c|c}
\hline Materyalist Eğilimler Ölçeği & Ort. & $\begin{array}{c}\text { Std. } \\
\text { Sapma }\end{array}$ \\
\hline Sahip Olunmayan Mallardan Duyulan Yoksunluk Hissi & & \\
\hline Şu an sahip olmadığım bazı şeylere sahip olsaydım hayatım daha iyi olurdu. & 3,24 & 1,19 \\
\hline Daha çok şey satın alma gücüm olsaydı daha mutlu olurdum. & 2,87 & 1,25 \\
\hline İstediğim her şeyi alamıyor olmak bazen canımı sıkıyor. & 3,13 & 1,21 \\
\hline Faktör maddelerinin ortalaması & 3,08 & \\
\hline Lüks Tüketim Eğilimi & & \\
\hline Pahalı evi, arabası veya kıyafetleri olan insanlara imreniyorum. & 2,00 & 1,18 \\
\hline İnsanları hayran bırakan şeylere sahip olmak istiyorum. & 2,57 & 1,37 \\
\hline Faktör maddelerinin ortalaması & 2,28 & \\
\hline Sahip Olunan Mallardan Duyulan Başarı Hissi & & \\
\hline Hayattaki en önemli başarılardan biri sahip olunan maddi varlıklardır. & 2.20 & 1.29 \\
\hline Sahip olduklarım, hayatımın nasıl olduğu hakkında çok şey söyler. & 3,11 & 1,27 \\
\hline Faktör maddelerinin ortalaması & 2,65 & \\
\hline
\end{tabular}

Tablo 1, "sahip olunmayan mallardan duyulan yoksunluk hissi” faktörüne verilen cevapların ortalama değerlerinin 3'e yakın $(3,08)$ olduğunu göstermektedir. Öte yandan "lüks tüketim eğilimi”" faktörüne verilen cevapların ortalama değerlerinin 2'ye yakın $(2,28)$ ve "sahip olunan mallardan duyulan başarı hissi” faktörüne verilen cevapların ise 2-3 arasında $(2,65)$ olduğu görülmektedir.

Tablo 2. Ahlaki Tüketim Eğilimi Ortalama ve Standart Sapma Değerleri (5’li Likert Ölçekli)

\begin{tabular}{l|c|c}
\hline Ahlaki Tüketim Eğilimi Ölçeği & Ort. & $\begin{array}{c}\text { Std. } \\
\text { Sapma }\end{array}$ \\
\hline Tüketimde Sahtekarlık Eğilimi & &, 877 \\
\hline Fiyat indirimlerinden yararlanmak için yaşını olduğundan küçük göstermek & 1,61 & 1,22 \\
\hline Satın almadığın bir ürünün indirim kuponunu kullanmak & 2,04 & 1,00 \\
\hline Son kullanım tarihi geçmiş indirim kuponu kullanmak & 1,81 & \\
\hline Faktör maddelerinin ortalaması & 1,82 & \\
\hline Korsan Ürün Kullanımı Eğilimi & 1,80 & 1,17 \\
\hline Hesap olması gerekenden daha az geldiğinde bunu çaktırmamak & 1,25 \\
\hline Bir albümü satın almak yerine internetten indirmek & 2,86 & 1,28 \\
\hline Bilgisayar yazılımlarını satın almadan korsanlarını indirip kullanmak & 2,42 & 1,35 \\
\hline Bir mağazada bir sürü farklı kıyafet deneyip hiçbirini satın almadan çımak & 3,17 & \\
\hline Faktör maddelerinin ortalaması & 2,56 & \\
\hline İinsiz Tüketim Eğilimi & & \\
\hline Bir markette parasını ödemeden bir şey alıp içmek & 1,39 & 0,805 \\
\hline $\begin{array}{l}\text { Başkasının internet ağına (wireless) ondan izinsiz bir şekilde bağlanarak internete } \\
\text { girmek }\end{array}$ & 1,72 & 0,905 \\
\hline $\begin{array}{l}\text { Sigorta şirketinden para alabilmek için aslında kayıp olan bir eşyayı çalınmış gibi } \\
\text { göstermek }\end{array}$ & 1,25 & 0,572 \\
\hline Faktör maddelerinin ortalaması & 1,45 & \\
\hline
\end{tabular}

Tablo 2, "tüketimde sahtekarlık eğilimi” faktörüne verilen cevapların ortalama değerlerinin 2'ye yakın $(1,82)$ olduğunu göstermektedir. Öte yandan "korsan ürün kullanımı eğilimi” faktörüne verilen cevapların ortalama değerinin 2-3 arasında $(2,56)$, "izinsiz tüketim eğilimi” faktörüne verilen cevapların ortalama değerinin ise 1'e yakın $(1,45)$ olduğu görülmektedir. 
Tablo 3. Gösterişçi Tüketim Ölçeği Ortalama ve Standart Sapma Değerleri (7’li Ölçek)

\begin{tabular}{l|c|c}
\hline Gösterişçi Tüketim Ölçeği & Ort. & $\begin{array}{c}\text { Std. } \\
\text { Sapma }\end{array}$ \\
\hline Ürünün Gösteriş ve Prestij Sağlama Özelliği & & \\
\hline Ürün alııken prestij, benim için önemli bir faktördür. & 4,16 & 2,02 \\
\hline $\begin{array}{l}\text { Bir ürünün diğer insanların ilgisini çekme özelliği, satın alma kararı vermemde } \\
\text { önemli bir unsurdur. }\end{array}$ & 3,40 & 2,28 \\
\hline Gösteriş amaçlı ürün satın alan insanlara karşı değilim. & 3,68 & 2,17 \\
\hline Daha prestijli bir ürün almak için extra para ödemekten çekinmiyorum. & 3,92 & 2,27 \\
\hline Faktör maddelerinin ortalaması & 3,79 & \\
\hline Ürünün Başkaları Üzerinde Etki Yaratma Özelliği & & \\
\hline $\begin{array}{l}\text { Hemen hemen tüm insanların, dikkat çekmek için ürün satın alma eğiliminde } \\
\text { olduklarını düs̈ünüyorum. }\end{array}$ & 4,35 & 2,19 \\
\hline İnsanlar birbirlerini sahip olduklarılyla yargılamaktadır. & 5,09 & 2,08 \\
\hline Diğer insanlar üzerinde etki yaratmayı gizlice umarak bir şeyler satın alıyorum. & 2,75 & 2,01 \\
\hline Faktör maddelerinin ortalaması & 4,06 & \\
\hline
\end{tabular}

Tablo 3 "ürünün gösteriş ve prestij sağlama özelliği" faktörüne verilen cevapların ortalama değerlerinin 4'e yakın $(3,79)$ olduğunu göstermektedir. Öte yandan "ürünün başkaları üzerinde etki yaratma özelliği”" faktör maddelerine verilen cevapların ortalamasının ise aynı şekilde 4'e yakın $(4,06)$ olduğu tespit edilmiştir.

Tablo 1, Tablo 2 ve Tablo 3'te yer alan ortalama değerler genel olarak incelendiğinde katılımcıların gösterişçi tüketim eğilimlerinin, ahlaki tüketim ve materyalist eğilimlerinden daha yüksek olduğu düşünülebilmektedir.

Çalışmanın hipotezlerinin testi için çoklu doğrusal regresyon analizi yapılmıştır. Regresyon analizi sonuçları aşağıdaki gibidir:

Tablo 4: Aylık Harcama Miktarı, Ahlaki Tüketim Eğilimi ve Materyalist Eğilimlerin, Ürünün Gösteriş ve Prestij Sağlama Özelliğine Olan Gösterişçi Tüketim Eğilimi Üzerindeki Etkisi

\begin{tabular}{|c|c|c|c|c|c|c|c|c|c|}
\hline & $\begin{array}{c}\text { Bağımsız } \\
\text { Değişkenler }\end{array}$ & $\begin{array}{l}\text { Std. } \\
\text { B. }\end{array}$ & $\begin{array}{l}\text { Korelas- } \\
\text { yonlar }\end{array}$ & Std. Hata & $\mathbf{t}$ & $\mathbf{p}$ & $\begin{array}{l}\text { Tole- } \\
\text { rans }\end{array}$ & VIF & SONUÇ \\
\hline $\mathbf{H}_{1}$ & & \multicolumn{7}{|c|}{ Ahlaki Tüketim Eğilimi } & \\
\hline $\mathbf{H}_{1 \mathbf{a}}$ & $\begin{array}{c}\text { Tüketimde } \\
\text { Sahtekarlık } \\
\text { Eğilimi } \\
\end{array}$ &, 124 & ,209 & ,048 & 2,603 & ,010 & 850 & 1,177 & Kabul \\
\hline $\mathbf{H}_{1 \mathrm{~b}}$ & $\begin{array}{c}\text { Korsan Ürün } \\
\text { Kullanımı } \\
\text { Eğilimi }\end{array}$ & ,089 & ,116 & ,046 & 1,925 &, 055 & ,905 & 1,105 & Ret \\
\hline $\mathbf{H}_{1 \mathrm{c}}$ & $\begin{array}{c}\text { İzinsiz Tüketim } \\
\text { Eğilimi }\end{array}$ & ,005 & ,037 & ,044 & ,118 & ,906 & ,992 & 1,008 & Ret \\
\hline $\mathbf{H}_{2}$ & & \multicolumn{7}{|c|}{ Materyalist Eğilim } & \\
\hline $\mathbf{H}_{2 \mathbf{a}}$ & $\begin{array}{c}\text { Sahip } \\
\text { Olunmayan } \\
\text { Mallardan } \\
\text { Duyulan } \\
\text { Yoksunluk Hissi }\end{array}$ &,- 005 & ,042 & ,047 &,- 114 & ,909 & 885 & 1,130 & Ret \\
\hline $\mathbf{H}_{2 b}$ & $\begin{array}{l}\text { Lüks Tüketim } \\
\text { Eğilimi }\end{array}$ & ,251 & ,283 & ,046 & 5,459 &, 000 & ,909 & 1,100 & Kabul \\
\hline
\end{tabular}




\begin{tabular}{|c|c|c|c|c|c|c|c|c|c|}
\hline $\mathbf{H}_{2 \mathrm{c}}$ & $\begin{array}{c}\text { Sahip Olunan } \\
\text { Mallardan } \\
\text { Duyulan Başarı } \\
\text { Hissi }\end{array}$ & ,340 & ,356 & ,045 & 7,575 & ,000 & 957 & 1,044 & Kabul \\
\hline $\mathbf{H}_{3}$ & $\begin{array}{c}\text { Aylık Harcama } \\
\text { Miktarı }\end{array}$ & ,129 & ,154 & ,000 & 2,910 & ,004 & 975, & 1,025 & Kabul \\
\hline $\begin{array}{l}\mathrm{R}^{2}=, 2 \\
\text { Düzel } \\
\mathrm{D}-\mathrm{W} \\
\text { F ist. } \\
\text { Beta }\end{array}$ & $\begin{array}{l}\text { miş } R^{2}=, 235 \\
=1,999 \\
\text { NOVA) }=18,40 \\
\text { bit) }=-, 237\end{array}$ & 0,00 & & & & & & & \\
\hline
\end{tabular}

Tablo 4, ürünün gösteriş ve prestij sağlama özelliğine olan gösterişçi tüketim eğilimi üzerinde aylık harcama miktarı, ahlaki tüketim eğilimi ve materyalist eğilimlerin etkisini göstermektedir. Tablo 4 incelendiğinde ürünün gösteriş ve prestij sağlama özelliğine olan gösterişçi tüketim eğilimi üzerinde katılımcının tüketimde sahtekarlık eğiliminin istatistiksel olarak anlamlı bir etkisi olduğu $(\mathrm{p}=, 010<, 05$; Std. B.=,124), sahtekarlık eğilimindeki 1 birimlik artışın, ürünün gösteriş ve prestij sağlama özelliğine olan gösterişçi tüketim eğilimi üzerinde $\% 12,4$ 'lük bir artışa sebep olduğu anlaşılmaktadır. Ahlaki tüketim eğiliminin diğer faktörleri olan korsan ürün kullanımı eğilimi $(p=, 055>, 05)$ ve ürünleri izin almadan tüketim eğiliminin ( $p=, 906>, 05)$ ise ürünün gösteriş ve prestij sağlama özelliğine olan gösterişçi tüketim eğilimi üzerinde istatistiksel olarak anlamlı bir etkisi tespit edilememiştir.

Materyalist eğilimin bir faktörü olan, katılımcının sahip olmadığı mallardan duyduğu yoksunluk hissinin, ürünün gösteriş ve prestij sağlama özelliğine olan gösterișçi tüketim eğilimi üzerinde istatistiksel olarak anlamlı bir etkisi tespit edilememiştir $(\mathrm{p}=, 909>, 05)$. Öte yandan materyalist eğilimin diğer faktörleri olan, katılımcının lüks tüketim eğilimi $(\mathrm{p}=, 000<, 05 ;$ Std. $\mathrm{B} .=, 251)$ ile sahip olduğu mallardan duyduğu başarı hissinin $(\mathrm{p}=, 000<, 05$; Std. $\mathrm{B} .=, 340)$ ise ürünün gösteriş ve prestij sağlama özelliğine olan gösterişçi tüketim eğilimi üzerinde istatistiksel olarak anlamlı etkileri olduğu tespit edilmiştir. Katılımcının lüks tüketim eğilimindeki 1 birimlik artışın, ürünün gösteriş ve prestij sağlama özelliğine olan gösterişçi tüketim eğiliminde \%25, $1^{\prime}$ lik; katılımcının sahip olduğu mallardan duyduğu başarı hissindeki 1 birimlik artışın ise ürünün gösteriş ve prestij sağlama özelliğine olan gösterişçi tüketim eğiliminde \%34'lük bir artışa sebep olduğu tespit edilmiştir.

Araştırmanın bir diğer bağımsız değişkeni olan aylık harcama miktarının ürünün gösteriş ve prestij sağlama özelliğine olan gösterişçi tüketim eğilimi üzerindeki etkisi anlamlı olarak tespit edilmiştir $(\mathrm{p}=, 004<, 05$; Std. $\mathrm{B} .=, 129)$. Katılımcının aylık harcama miktarındaki 1 birimlik artışın, ürünün gösteriş ve prestij sağlama özelliğine olan gösterişçi tüketim eğilimi üzerinde\%12,9'luk bir artışa sebep olduğu tespit edilmiştir.

Tablo 4'ün altında yer alan düzeltilmiş $\mathrm{R}^{2}$ değerine bakıldığında söz konusu bağımsız değişkenlerin, ürünün gösteriş ve prestij sağlama özelliğine olan gösterişçi tüketim eğilimindeki değişimin \%23,5'ini açıkladığı anlaşılmaktadır. F istatistiğine bakıldığında da modelin bir bütün olarak anlamlı olduğu anlaşılmaktadır $(\mathrm{p}=, 000<, 05)$. Dolayısıyla elde edilen istatistik değerleri sonucunda söz konusu modelin denklemi şu şekilde gösterilebilmektedir:

Ürünün Gösteriş ve Prestij Sağlama Özelliğine Olan Gösterişçi Tüketim Eğilimi=0,237+0,124(Tüketimde Sahtekarlık Eğilimi)+0,251(Lüks Tüketim Eğilimi) +0,340 (Sahip Olunan Mallardan Duyulan Başarı Hissi) + 0,129(Aylık Harcama Miktarı)

$\mathrm{Bu}$ durumda her şey sıfir olduğunda katılımcının, ürünün gösteriş ve prestij sağlama özelliğine olan gösterişçi tüketim eğiliminin $-0,237$ birim olduğu görülmektedir. Ayrıca katılımcıların, ürünün gösteriş ve prestij sağlama özelliğine olan gösterişçi tüketim eğilimlerindeki artışta pozitif yönde en çok etkili olan değişkenin sahip olunan mallardan duyulan başarı hissi olduğu anlaşılmaktadır. 
Tablo 5: Aylık Harcama Miktarı, Ahlaki Tüketim Eğilimi ve Materyalist Eğilimlerin, Ürünün Başkaları Üzerinde Etki Yaratma Özelliğine Olan Gösterişçi Tüketim Eğilimi Üzerindeki Etkisi

\begin{tabular}{|c|c|c|c|c|c|c|c|c|c|}
\hline & $\begin{array}{c}\text { Bağımsız } \\
\text { Değişkenler }\end{array}$ & $\begin{array}{l}\text { Std. } \\
\text { B. }\end{array}$ & $\begin{array}{l}\text { Korelas- } \\
\text { yonlar }\end{array}$ & $\begin{array}{l}\text { Std. } \\
\text { Hata }\end{array}$ & $\mathbf{t}$ & $\mathbf{p}$ & $\begin{array}{l}\text { Tole- } \\
\text { rans }\end{array}$ & VIF & SONUÇ \\
\hline $\mathbf{H}_{1}$ & & \multicolumn{7}{|c|}{ Ahlaki Tüketim Eğilimi } & \\
\hline $\mathbf{H}_{1 \mathbf{a}}$ & $\begin{array}{c}\text { Tüketimde } \\
\text { Sahtekarlık Eğilimi }\end{array}$ &,- 059 & ,049 & 052 & $-1,131$ & ,259 & 850 & 1,177 & Ret \\
\hline $\mathbf{H}_{1 b}$ & $\begin{array}{c}\text { Korsan Ürün } \\
\text { Kullanımı Eğilimi }\end{array}$ & ,120 & , 120 & ,051 & 2,368 & ,018 & ,905 & 1,105 & Kabul \\
\hline $\mathbf{H}_{1 \mathrm{c}}$ & $\begin{array}{c}\text { İzinsiz Tüketim } \\
\text { Eğilimi }\end{array}$ & $\begin{array}{l}-008 \\
\end{array}$ & ,007 & ,049 &,- 159 & ,873 & ,992 & 1,008 & Ret \\
\hline $\mathbf{H}_{2}$ & & \multicolumn{7}{|c|}{ Materyalist Eğilim } & \\
\hline $\mathbf{H}_{2 \mathbf{a}}$ & $\begin{array}{l}\text { Sahip Olunmayan } \\
\text { Mallardan Duyulan } \\
\text { Yoksunluk Hissi }\end{array}$ & ,147 &, 153 & ,051 & 2,852 & 005 & 885 & 1,130 & Kabul \\
\hline $\mathbf{H}_{2 b}$ & $\begin{array}{c}\text { Lüks Tüketim } \\
\text { Eğilimi }\end{array}$ & ,235 & ,210 & ,051 & 4,630 & 000 & ,909 & 1,100 & Kabul \\
\hline $\mathbf{H}_{2 \mathrm{c}}$ & $\begin{array}{c}\text { Sahip Olunan } \\
\text { Mallardan Duyulan } \\
\text { Başarı Hissi }\end{array}$ & ,019 & ,039 & ,049 &, 384 & ,701 & ,957 & 1,044 & Ret \\
\hline $\mathbf{H}_{3}$ & $\begin{array}{c}\text { Aylık Harcama } \\
\text { Miktarı }\end{array}$ & ,070 & ,072 & ,000 & 1,434 & ,152 & ,975 & 1,025 & Ret \\
\hline \multicolumn{10}{|c|}{$\begin{array}{l}\mathrm{R}^{2}=, 089 \\
\text { Düzeltilmiş } \mathrm{R}^{2}=, 072 \\
\text { D-W ist. }=1,709 \\
\text { F ist. (ANOVA) }=5,433[0,000] \\
\text { Beta (Sabit) }=-, 132\end{array}$} \\
\hline
\end{tabular}

Tablo 5, ürünün başkaları üzerinde etki yaratma özelliğine olan gösterişçi tüketim eğilimi üzerinde aylık harcama miktarı, ahlaki tüketim eğilimi ve materyalist eğilimlerin etkisini göstermektedir. Tablo 5 incelendiğinde ürünün başkaları üzerinde etki yaratma özelliğine olan gösterișçi tüketim eğilimi üzerinde ahlaki tüketim eğiliminin bir faktörü olan tüketimde sahtekarlık eğiliminin istatistiksel olarak anlamlı bir etkisi olmadığ 1 tespit edilmiştir $(\mathrm{p}=, 259>, 05)$. Ahlaki tüketim eğiliminin bir diğer faktörü olan korsan ürün kullanımı eğiliminin ise ürünün başkaları üzerinde etki yaratma özelliğine olan gösterişçi tüketim eğilimi üzerinde istatistiksel olarak anlamlı bir etkisi olduğu tespit edilmiştir $(\mathrm{p}=, 018<, 05$; Std. $\mathrm{B} .=, 120)$. Katılımcının korsan ürün kullanma eğilimindeki 1 birimlik artışın, ürünün başkaları üzerinde etki yaratma özelliğine olan gösterişçi tüketim eğiliminde \%12'lik bir artı̧̧a sebep olduğu tespit edilmiştir. Öte yandan ahlaki tüketim eğiliminin bir diğer faktörü olan, ürünleri izin almadan tüketim eğiliminin ise ürünün başkaları üzerinde etki yaratma özelliğine olan gösterişçi tüketim eğilimi üzerinde istatistiksel olarak anlamlı bir etkisi tespit edilememiştir $(\mathrm{p}=, 873>, 05)$.

Materyalist eğilimin faktörleri olan, katılımcının sahip olmadığı mallardan duyduğu yoksunluk hissinin $(\mathrm{p}=, 005<, 05$; Std. $\mathrm{B} .=, 147)$ ve lüks tüketim eğiliminin $(\mathrm{p}=, 000<, 05$; Std. $\mathrm{B} .=, 235)$ ürünün başkaları üzerinde etki yaratma özelliğine olan gösterişçi tüketim eğiliminde istatistiksel olarak anlamlı bir etkisi olduğu tespit edilmiştir. Sahip olunmayan mallardan duyulan yoksunluk hissindeki 1 birimlik artışın, ürünün başkaları üzerinde etki yaratma özelliğine olan gösterişçi tüketim eğiliminde \%14.7'lik; lüks tüketim eğilimindeki 1 birimlik artışı ise ürünün başkaları üzerinde etki yaratma özelliğine olan gösterişçi tüketim eğiliminde $\% 23.5$ 'lik bir artışa sebep olduğu tespit edilmiştir. Materyalist eğilimin bir diğer faktörü olan, sahip olunan mallardan duyulan başarı hissinin ise ürünün başkaları üzerinde etki yaratma özelliğine olan gösterişçi tüketim eğilimi üzerinde istatistiksel olarak anlamlı bir etkisi tespit edilememiştir $(\mathrm{p}=, 701>, 05)$. 
Araştırmanın bir diğer bağımsız değişkeni olan aylık harcama miktarının, ürünün başkaları üzerinde etki yaratma özelliğine olan gösterişçi tüketim eğilimi üzerinde istatistiksel olarak anlamlı bir etkisi tespit edilememiştir $(\mathrm{p}=, 152>, 05)$.

Tablo 5'in altında yer alan düzeltilmiş $\mathrm{R}^{2}$ değerine bakıldığında söz konusu bağımsız değişkenlerin, ürünün başkaları üzerinde etki yaratma özelliğine olan gösterişçi tüketim eğilimindeki değişimin \% 7.2'sini açıkladığı anlaşılmaktadır. $\mathrm{F}$ istatistiğine bakıldığında da modelin bir bütün olarak anlamlı olduğu anlaşılmaktadır $(\mathrm{p}=, 000<, 05)$. Dolayısıyla elde edilen istatistik değerleri sonucunda söz konusu modelin denklemi şu şekilde gösterilebilmektedir:

Ürünün Başkaları Üzerinde Etki Yaratma Özelliğine Olan Gösterişçi Tüketim Eğilimi= 0,132+0,120(Korsan Ürün Kullanımı Eğilimi)+0,147(Sahip Olunmayan Mallardan Duyulan Yoksunluk Hissi)+0,235(Lüks Tüketim Ĕ̈ilimi)

Bu durumda her şey sıfır olduğunda katılımcının, ürünün başkaları üzerinde etki yaratma özelliğine olan gösterişçi tüketim eğiliminin -0,132 birim olduğu görülmektedir. Ayrıca katılımcıların, ürünün başkaları üzerinde etki yaratma özelliğine olan gösteriş̧̧i tüketim eğilimlerindeki artışta pozitif yönde en çok etkili olan değişkenin lüks tüketim eğilimi olduğu anlaşılmaktadır.

Cinsiyet değişkeninin hem ürünün gösteriş ve prestij sağlama özelliğine olan gösteriş̧̧i tüketim eğilimi hem de ürünün başkaları üzerinde etki yaratma özelliğine olan gösterişçi tüketim eğilimi üzerinde anlamlı bir farklılık oluşturup oluşturmadığının tespiti için bağımsız örneklem t testi yapılmıştır.

Tablo 6: Cinsiyet Değişkeninin Ürünün Gösteriş ve Prestij Sağlama Özelliğine Olan Gösterişçi Tüketim Eğilimi Üzerinde Oluşturduğu Farklı1ıklara Yönelik Bağımsız Örneklem t Testi Sonuçları

\begin{tabular}{|c|c|c|c|c|c|c|c|c|}
\hline $\begin{array}{l}\text { Bağımlı } \\
\text { Değişken }\end{array}$ & & \multicolumn{2}{|c|}{$\begin{array}{c}\text { Varyans Eşitliği } \\
\text { için Levene } \\
\text { Testi }\end{array}$} & \multicolumn{5}{|c|}{ Ortalamaların Eşitliği içi t Testi } \\
\hline \multirow{3}{*}{$\begin{array}{l}\text { Ürünün } \\
\text { Gösteriş ve } \\
\text { Prestij } \\
\text { Sağlama } \\
\text { Özelliğine } \\
\text { Olan } \\
\text { Gösterişçi } \\
\text { Tüketim } \\
\text { Eğilimi }\end{array}$} & & F. & Sig. & $\mathbf{t}$ & Sd. & $\begin{array}{l}\text { Sig. (çift } \\
\text { kuyruk) }\end{array}$ & $\begin{array}{l}\text { Ort. } \\
\text { Farki }\end{array}$ & $\begin{array}{l}\text { Std. Hata } \\
\text { Farki }\end{array}$ \\
\hline & $\begin{array}{l}\text { Varyansların eşitliği } \\
\text { varsayıldığında }\end{array}$ & 1,617 & 204 & 6,017 & 398 & ,000 & ,85750 & ,14252 \\
\hline & $\begin{array}{ll}\text { Varyansların } & \text { eşit } \\
\text { olmadığı } & \\
\text { varsayıldığında } & \end{array}$ & & & 6,017 & 395,347 & ,000 & ,85750 & ,14252 \\
\hline
\end{tabular}

Tablo 6 incelendiğinde kadınlar ve erkekler arasında ürünün gösteriş ve prestij sağlama özelliğine olan gösterişçi tüketim eğilimi açısından istatistiksel olarak anlamlı bir farklılık olduğu anlaşılmaktadır (Sig.=,000<,05). Söz konusu farklılığın tespiti için Tablo 7'nin incelenmesi gerekir.

Tablo 7: Cinsiyet Değişkeninin Ürünün Gösteriş ve Prestij Sağlama Özelliğine Olan Gösterişçi Tüketim Eğilimi Üzerinde Oluşturduğu Farklılıklara Yönelik Grup İstatistikleri

\begin{tabular}{|c|c|c|c|c|c|}
\hline \multirow{2}{*}{$\begin{array}{lr}\text { Ürünün } & \text { Gösteriş ve } \\
\text { Prestii } & \text { Saŏlama }\end{array}$} & Bağımsız Değişken & $\mathbf{N}$ & Ort. & Std. Sapma & $\begin{array}{l}\text { Std. Hata } \\
\text { Ort. }\end{array}$ \\
\hline & Erkek & 200 & 4,22 & 1,48 & ,10482 \\
\hline \multicolumn{6}{|l|}{ Özelliğine $\quad$ Olan } \\
\hline Gösterişçi Tüketim & & & & & \\
\hline & Kadın & 200 & 3,36 & 1,36 & ,09656 \\
\hline
\end{tabular}

Tablo 7 incelendiğinde erkeklerin, ürünün gösteriş ve prestij sağlama özelliğine olan gösterişçi tüketim eğilimi ortalamasının 4,22; kadınların ise 3,36 olduğu anlaşılmaktadır. Söz konusu değişkenin 7'li ölçek ile ölçüldüğü göz önünde bulundurulduğunda erkeklerin genelinin, ürünün gösteriş ve prestij sağlama özelliğine olan gösterişçi tüketim eğiliminde kararsız, kadınların genelinin ise böyle bir eğilim içerisinde olmadıklarını ifade ettikleri yorumu yapılabilir. 
Tablo 8: Cinsiyet Değişkeninin Ürünün Başkaları Üzerinde Etki Yaratma Özelliğine Olan Gösterişçi Tüketim Eğilimi Üzerinde Oluşturduğu Farklılıklara Yönelik Bağımsız Örneklem t Testi Sonuçları

\begin{tabular}{|c|c|c|c|c|c|c|c|c|}
\hline $\begin{array}{l}\text { Bağımlı } \\
\text { Değişken }\end{array}$ & & \multicolumn{2}{|c|}{$\begin{array}{c}\text { Varyans } \\
\text { Eşitliği için } \\
\text { Levene Testi }\end{array}$} & \multicolumn{5}{|c|}{ Ortalamaların Eşitliği içi t Testi } \\
\hline \multirow{3}{*}{$\begin{array}{l}\text { Ürünün } \\
\text { Başkaları } \\
\text { Üzerinde } \\
\text { Etki } \\
\text { Yaratma } \\
\text { Özelliğine } \\
\text { Olan } \\
\text { Gösterişçi } \\
\text { Tüketim } \\
\text { Eğilimi }\end{array}$} & & F. & Sig. & $\mathbf{t}$ & Sd. & $\begin{array}{l}\text { Sig. (çift } \\
\text { kuyruk) }\end{array}$ & $\begin{array}{l}\text { Ort. } \\
\text { Farki }\end{array}$ & $\begin{array}{l}\text { Std. Hata } \\
\text { Farkı }\end{array}$ \\
\hline & $\begin{array}{l}\text { Varyansların eşitliği } \\
\text { varsayıldığında }\end{array}$ & ,005 & ,943 & 3,227 & 398 & ,001 & ,47667 & , 14772 \\
\hline & $\begin{array}{ll}\text { Varyansların } & \text { eşit } \\
\text { olmadığı } & \\
\text { varsayıldığında }\end{array}$ & & & 3,227 & 397,987 & ,001 & ,47667 &, 14772 \\
\hline
\end{tabular}

Tablo 8 incelendiğinde kadınlar ve erkekler arasında ürünün başkaları üzerinde etki yaratma özelliğine olan gösterişçi tüketim eğilimi açısından istatistiksel olarak anlamlı bir farkl1lık olduğu anlaşılmaktadır (Sig.=,001<,05). Söz konusu farklılığın tespiti için Tablo 9'un incelenmesi gerekir.

Tablo 9: Cinsiyet Değişseninin Ürünün Başkaları Üzerinde Etki Yaratma Özelliğine Olan Gösterişçi Tüketim Eğilimi Üzerinde Oluşturduğu Farklllıklara Yönelik Grup İstatistikleri

\begin{tabular}{|c|c|c|c|c|c|c|}
\hline \multirow{3}{*}{$\begin{array}{l}\text { Ürünün } \\
\text { Üzerinde Etki } \\
\text { Özelliğine } \\
\text { Gösterişçi } \\
\text { Eğilimi }\end{array}$} & \multirow{2}{*}{$\begin{array}{r}\text { Başkaları } \\
\text { Yaratma } \\
\text { Olan } \\
\text { Tüketim }\end{array}$} & Bağımsız Değişken & $\mathbf{N}$ & Ort. & Std. Sapma & $\begin{array}{c}\text { Std. Hata } \\
\text { Ort. }\end{array}$ \\
\hline & & Erkek & 200 & 4,30 & 1,48 &, 10475 \\
\hline & & Kadın & 200 & 3,83 & 1,47 & ,10416 \\
\hline
\end{tabular}

Tablo 9 incelendiğinde erkeklerin, ürünün başkaları üzerinde etki yaratma özelliğine olan gösterişçi tüketim eğilimi ortalamasının 4,30; kadınların ise 3,83 olduğu anlaşılmaktadır. Söz konusu değişkenin 7'li ölçek ile ölçüldüğü göz önünde bulundurulduğunda erkeklerin genelinin ürünün başkaları üzerinde etki yaratma özelliğine olan gösterişçi tüketim eğiliminde kararsız, kadınların genelinin ise söz konusu eğilimde kararsıza yakın bir tutum gösterdikleri anlaşılmaktadır. Elde edilen sonuçlar kadınların, ürünün gösteriş ve prestij sağlama özelliğine olan gösterişçi tüketim eğiliminde negatif bir tutum sergilerken ürünün başkaları üzerinde etki yaratma özelliğine olan gösterişçi tüketim eğiliminde kararsıza yakın bir tutum içerisinde olduğunu göstermektedir. Genel olarak ise erkeklerin kadınlara göre gösterişçi tüketime daha eğilimli oldukları yorumu yapılabilmektedir.

\section{TARTISYMA VE SONUÇ}

Araştırmada yapılan açımlayıcı faktör analizi sonucunda gösterişçi tüketimin "ürünün gösteriş ve prestij sağlama özelliğine olan gösteriş̧̧i tüketim eğilimi” ve "ürünün başkaları üzerinde etki yaratma özelliğine olan gösterişçi tüketim eğilimi” olmak üzere iki farklı boyutu ortaya çıkmıştır. Öte yandan ahlaki tüketim eğilimine yapılan faktör analizi sonucunda bu değişkenin "tüketimde sahtekarlık eğilimi", "korsan ürün kullanımı eğilimi” ve "ürünü izinsiz tüketim eğilimi” olmak üzere 3 boyutu; materyalist eğilime yapılan faktör analizi sonucunda ise söz konusu değişkenin "sahip olunmayan mallardan duyulan yoksunluk hissi", "lüks tüketim eğilimi" ve "sahip olunan mallardan duyulan başarı hissi" olmak üzere 3 farklı boyutu tespit edilmiştir.

Yapılan çoklu doğrusal regresyon analizi sonucunda ürünün gösteriş ve prestij sağlama özelliğine olan gösterişçi tüketim eğilimi üzerinde tüketimde sahtekarlık eğilimi, lüks tüketim eğilimi ve sahip olunan mallardan duyulan başarı hissinin istatistiksel olarak anlamlı etkide olduğu ve söz konusu etkilerin pozitif yönde olduğu tespit edilmiştir. Dolayısıyla analiz sonuçlarına göre kişinin fiyat indirimlerinden yararlanmak için yaşını olduğundan küçük göstermesi gibi sahtekarlık eğilimlerindeki artış, kişinin gösteriş amaçlı ürün satın alma ve/veya daha prestijli bir ürün satın almak için ekstra para ödeme gibi eğilimlerinde de artışa sebep olacağı düşünülebilir. Öte yandan kişinin pahalı ve başkalarında hayranlık 
bırakan mallara sahip olma isteği gibi lüks tüketim eğilimindeki artışın da gösteriş ve prestij amaçlı ürün satın alma eğiliminde artışa sebep olacağı düşünülebilmektedir. Kişinin sahip olduğu malları hayattaki en önemli başarılarından biri olarak görmesi gibi sahip olduklarından duyduğu başarı hissindeki artış da gösteriş ve prestij amaçlı ürün satın alma eğiliminde artışa sebep olacağ düşünülebilmektedir. $\mathrm{Bu}$ sonuçlardan yola çıkılarak kişinin sahip olduğu maddi varlıklara atfettiği önem ve verdiği değer arttıkça, gösteriş ve prestij amaçlı ürün satın alma eğiliminin de artacağı düşünülebilir.

Regresyon analizi sonucunda elde edilen bir diğer sonuç ise korsan ürün kullanımı eğilimi, sahip olunmayan mallardan duyulan yoksunluk hissi ve lüks tüketim eğilimindeki artışın, ürünün başkaları üzerinde etki yaratma özelliğine olan gösterişçi tüketim eğiliminde de artışa sebep olduğudur. Dolayısıyla analiz sonuçlarına göre bir ürünü (albüm vb. gibi) satın almak yerine internetten indiren ya da ürünlerin korsanlarını satın alan kişilerin, ürünleri başkaları üzerinde etki yaratmak için satın alma ihtimalleri daha yüksek olmaktadır. Buna ilaveten daha çok satın alarak hayatının daha iyi olacağını düşünen birinin başkaları üzerinde etki yaratmak amacıyla ürün satın alma ihtimali daha yüksek olmaktadır. Ayrıca araştırma sonuçlarına göre, pahalı eşyalara sahip kişilere imrenen bir kişinin de başkaları üzerinde etki yaratmak amacıyla ürün satın alma eğilimi daha yüksek olacaktır.

Regresyon analizi sonuçlarına göre cinsiyet, ürünün gösteriş ve prestij sağlama özelliğine olan gösterişçi tüketim eğilimi üzerinde etkili bir değişken olarak ortaya çıkmıştır. Dolayısıyla söz konusu değişken açısından kadınlar ve erkekler arasında anlamlı bir fark olduğu düşünüldüğünden bağımsız örneklem t testi yapılmış ve elde edilen sonuçlar, kadınlar ve erkekler arasında ilgili değişken açısından farklılık olduğunu göstermiştir. Genel olarak erkeklerin, ürünün gösteriş ve prestij sağlama özelliğine olan gösterişçi tüketim eğiliminde kararsız, kadınların ise böyle bir eğilim içerisinde olmadıklarını ifade ettikleri tespit edilmiştir. Cinsiyet değişkeni ürünün başkaları üzerinde etki yaratma özelliğine olan gösterişçi tüketim eğiliminde de etkili bir değişken olarak tespit edilmiştir. Bu sonuçtan yola çıkılarak ürünün başkaları üzerinde etki yaratma özelliğine olan gösteriş̧̧i tüketim eğiliminde de kadınlar ve erkekler arasında anlamlı bir fark olduğu düşünüldüğünden bağımsız örneklem t testi yapılmış ve elde edilen sonuçlar, kadınlar ve erkekler arasında ilgili değişken açısından farklılık olduğunu göstermiştir. Genel olarak erkeklerin ürünün başkaları üzerinde etki yaratma özelliğine olan gösterişçi tüketim eğiliminde kararsız, kadınların ise söz konusu eğilimde kararsıza yakın bir tutum gösterdikleri anlaşılmaktadır. Bu sonuçlar yorumlanırken anketi dolduran kişilerin genel olarak toplumda negatif olarak değerlendirilen gösteriş amaçlı tüketim konusunda gerçek tutumlarını ifade etmeme ihtimalleri olduğunun göz önünde bulundurulması gerekmektedir.

Regresyon analizi sonucunda elde edilen bir diğer sonuç da aylık harcama miktarı arttıkça kişinin gösteriş ve prestij amaçlı ürün satın alma eğiliminin de artış göstermesidir. Aylık harcama miktarı ile başkaları üzerinde etki yaratmak amacıyla ürün satın alma eğilimi arasında ise herhangi bir ilişki tespit edilememiştir. Bu sonuçlar yorumlandığında kişilerin başkaları üzerinde etki yaratmak için çok fazla harcama yapmaya gerek olmadığını düşündükleri, gösteriş ve prestij sahibi olmayı ise maddiyatla ilişkilendirdikleri sonucuna varılabilir.

\section{7. ÖNERILER VE KISITLAR}

$\mathrm{Bu}$ çalışmada cinsiyet, aylık harcama miktarı, materyalist eğilim ve ahlaki tüketim değişkenlerinin gösterişçi tüketim eğilimi üzerindeki olası etkileri incelenmiş̧ir. Bu etkileri incelemek amaciyla 200 erkek ve 200 kadından oluşan lisans öğrencileri üzerinde çalışılmıştır. Çalışmanın örnekleminde çalışan kesim olmadığından, çevreye duyarlı satın alma, yeşil ve organik ürün satın alma vb. gibi ahlaki tüketim eğilimi göstergelerinin ölçümü yapılamamıştır; çünkü söz konusu ürünler, yeşil olmayan ürünlere göre daha pahalıdır ve öğrencilerden bu tür satın alma eğilimi beklemek mümkün olmamaktadır. Bu sebeple ahlaki tüketim eğilimi tespit edilirken belli bir ölçekte sınırlı kalınmıştır. İleriki çalışmalarda örnekleme çalışan kesimin dahil edilmesi, ahlaki tüketim eğiliminin daha etkin bir şekilde ölçülmesini sağlayabilir. Buna ilaveten farklı meslek gruplarının gösterişçi tüketim eğilimlerinin karşılaştırıldığı çalışmalar yapılarak ilgili literatür geliştirilebilir. Ayrıca söz konusu araştırmanın örneklemini birbirine yakın yaşlara sahip bireyler oluşturmaktadır. Bu nedenle yaş değişkeninin gösteriş̧̧i tüketim eğilimi üzerindeki olası etkisi incelenememiştir. İleriki çalışmalarda gösterişçi tüketim açısından jenerasyonlar arasında fark olup olmadığının incelemesi de yapılarak literatür geliştirilebilir. 
Çalışmanın değişkenleri olan materyalist eğilim, gösterişçi tüketim ve ahlaki tüketim kavramları, tanımları ve kapsamları gereği tüketicilerin kendilerini rahat bir şekilde ifade edebilecekleri kavramlar olmayabilmektedir. Şöyle ki kişi ahlaki tüketim değişkeninin bir ifadesi olan "bir markette parasını ödemeden bir şey alıp içmek" veya "fiyat indirimlerinden yararlanmak için yaşını olduğundan küçük göstermek" gibi durumları kişi daha önce gerçekleştirmiş olsa bile bunun ahlaki olmadığını düşündüğ̈̈nden gerçeği yansıtmayan cevaplar verebilmektedir. Söz konusu araştırma da kişinin sözlü ifadelere verdiği puanlamaya dayandığından gerçeği yansıtmayan sonuçların elde edilme ihtimali olduğunun unutulmamas1 gerekir. Bu nedenle ve örneklemin sadece bir üniversitenin bir fakültesinde okumakta olan lisans öğrencilerinden oluşması sebebiyle genelleştirilmesi söz konusu değildir. İleriki çalışmalarda konuyla ilgili olarak derinlemesine görüşme tekniğinden yararlanılarak veri toplama yoluna gidilmesi, kişilerin söz konusu eğilimlerine olan tutumlarında daha gerçekçi sonuçlar elde edilmesini sağlayabilecektir. Ayrıca kişinin herkesin görebileceği ortamda alışveriş yaparken gösterişçi tüketim eğilimine daha yatkın olabileceği düşüncesinden hareketle farklı ortamlardaki tüketim davranışlarının gözlem yoluyla da incelendiği çalışmalar yapılabilir.

Son olarak bu çalışmada mateyalizm eğilimi yüksek ve düşük olanların gösterişçi tüketim eğilimi açısından farklılaşıp farklılaşmadığı incelenmemiştir. İleriki çalışmalarda materyalizm eğilimi açısından farklılaşan tüketici gruplarının gösterişçi tüketim eğilimlerinin farklılaşıp farklılaşmadığının incelendiği çalışmalar da yapılarak literatür geliştirebilir.

\section{KAYNAKÇA}

Ackerman, F. (1997). Consumed in theory: Alternative perspectives on the economics of consumption. J. Econ., 31(3), 651-64.

Açıkalın, S. ve Erdoğan, L. (2004). Veblen'ci gösteriş amaçlı tüketim. SÜ İ̈BF Sosyal ve Ekonomik Araştırmalar Dergisi, 4(7),8-39.

Aslay, F., Ünal, S. ve Akbulut, Ö. (2013). Materyalizmin statü tüketimi üzerindeki etkisini belirlemeye yönelik bir araştırma. Atatürk Üniversitesi İktisadi ve İdari Bilimler Dergisi, 27(2), 43-62.

Atik, D. ve Şahin, D.Y. (2011). Conspicuous consumption of the neglected majority: low-income consumers in a non-western culture. African Journal of Business Management, 5(13), 5330-5335.

Aydın, G. ve Karamehmet, B. (2015). Y jenerasyonunda sözsüz iletişim yöntemi olarak gösterişçi tüketim kullanımıyla ilgili deneysel bir çalışma. İstanbul Arel Üniversitesi İletişim Çalışmaları Dergisi, 4(7), 107-126.

Barzoki, M.H., Tavakol, M. ve Vahidnia, A. (2014). Effects of sexual objectification on conspicuous consumption and materialism. Sex Res Soc Policy, 11, 153-162.

Belk, R.W. (1983). Wordly possessions: Issues and criticisms. in advances in consumer research. 10, eds. Richard P. Bagozzi and Alice M. Tybout, Ann Arbor, Michigan: Association for Consumer Research, 514-519.

Belk, R.W. (1985). Materialism: Traits aspects of living in the material world. Journal of Consumer Research, 12(December), 265-280.

Belk, R.W. ve Pollay, R.W. (1985). Materialism and status appeals in Japanese and US print advertising. International Marketing Review, 2(4), 38-47.

Belk, R.W. (1987). Material values in the comics: A content analysis of comic books featuring themes of wealth. Journal of Consumer Research, 14(June), 26-42.

Cho, S. ve Krasser, A.H. (2011). What makes us care? The impact of cultural values, individual factors, and attention to media content on motivation for ethical consumerism. International Social Science Review, 86(1/2), 3-23. 
Christopher, A.N., Victoria, K., Kristen, M.A., Leonard, W. ve Noel, H. (2004). Materialism and affective well-being: The role of social support. Personality and Individual Differences, 37, 463470 .

Csikszentmihalyi, M. ve Rochberg-Halton, E. (1981). The meaning of things: Domestic symbols and the self. Cambridge: Cambridge University Press.

Dawson, S. ve Cavell, J. (1987). Status recognition in the 1980s: Invidious distinction revisited. in NAAdvances in Consumer Research, 14, eds. Melanie Wallendorf and Paul Anderson, Provo, UT: Association for Consumer Research, 487-491.

De Pelsmacker, P., Driessen, L. ve Rayp, G. (2005). Do consumers care about ethics? Willingness to pay for fair trade coffee. Journal of Consumer Affairs, 39(2), 361-383.

Eastman, K.J., Goldsmith, R.E. ve Flynn, L.R. (1999). Status consumption in consumer behaviour: Scale development and validation. Journal of Marketing Theory and Practice, (Summer), 41-52.

Griskevicius, V., Kenrick, D.T., Tybur, J.M., Miller, G.F., Sundie, J.M. ve Cialdini, R.B. (2007). Blatant benelovence and conspicuous consumption: When romantic motives elicit strategies costly signals. Journal of Personality and Social Psychology, 93(1), 85-102.

Griskevicius, V. (2008). Conspicuous conservation: Pro-environmental consumption and status competition. Unpublished PHD. Thesis, Arizona State University, USA.

Güleç, C. (2015). Thorstein Veblen ve gösterişçi tüketim kavramı. Sosyal Bilimler Enstitüsü Dergisi, 38, $62-82$.

Hardy, C.L. ve Van Vugt, M. (2006). Nice guys finish first: The competitive altruism hypothesis. Personality and Social Psychology Bulletin, October 1.

Hayakawa, H. ve Venieris, Y. (1977). Consumer interdependence via reference groups. J. Polit. Econ., 85(3), 599-616.

Hartmann, P. ve Ibanez, V.A. (2012). Consumer attitude and purchase intention toward green energy brands: The roles of psychological benefits and environmental concern. Journal of Business Research, 65(2012),1254-1263.

Kilbourne, W.E. ve Pickett, G. (2008). How materialism affects environmental beliefs, concern and environmentally responsible behavior. Journal of Business Research, 61(9), 885-893.

Lee, J., Ko, E. ve Megehee, C.M. (2015). Social benefits of brand logos in presentation of self in cross and same gender influence contexts. Journal of Business Research, 68,1341-1349.

Lumpkin, J.R. ve Darden, W.R. (1982). Relating television preference viewing to shopping orientation. lifestyles and demographics. Journal of Advertising, 11, 56-57.

Mason, R.S. (1981). Conspicuous consumption. New York: St. Martin's Press.

Moschis, G.P. (1981). Patterns of consumer learning. Journal of Academy of Marketing Science, 9(2), 110.126 .

Muncy, J.A. ve Vitell, S.J. (1992). Consumer ethics: An investigation of ethical beliefs of the final consumer. Journal of Business Reearch, 24, 297-311.

O'cass, A. ve Mcewen, H. (2005). Exploring consumer status and conspicuous consumption. Journal of Consumer Behaviour, 4(1), 25-39.

Othman, N. (1989). Materialism: Its relationship to some selected aspect of consumer behavior. Unpublished Phd Thesis, Graduate College of the Oklahoma State University, USA.

Parker, R.S., Diana, H. ve Charles, H. (2009). The perception of materialism in a global market: A comparison of younger Chinese and United States consumers. Journal of International Business and Cultural Studies, 1-13. $10 \quad$ Haziran 2019 tarihinde https://www.aabri.com/manuscripts/09148.pdf adresinden erişildi. 
Porter, J.N. (1967). Consumption patterns of professors and businessmen: A pilot study of conspicuous consumption and status. Sociological Inquiry, 37(Spring), 255-265.

Richins, M.L. (1987). Media, materialism, and human happiness. In Advances in Consumer Research. 14, eds. Melanie Wallendorf and Paul Anderson, Provo, Utah: Association for Consumer Research, 352-356.

Richins, M.L. ve Dawson, S. (1992). A consumer values orientation for materialism and its measurement: Scale development and validation. Journal of Consumer Research, 19(3), 303-316.

Sundıe, J.M., Kenrick, D.T., Griskevicius, V., Tybur, J.M., Vohs, K.D. ve Beal, D.J. (2011). Peacocks, porches, and Thorsten Veblen: Conspicuous consumption as a sexual signalling system. Journal of Personality and Social Psychology, 100(4), 664-680.

Veblen, T. (1899). The theory of the leisure class: An economic study of institutions. London: Unwin Books (Reprinted New York: Dover Publications, 1994).

Vitell, S.J., Lumpkin, J.R. ve Rawwas, M.Y.A. (1991). Consumer ethics: An investigation of the ethical beliefs of elderly consumers. Journal of Business Ethics, 10, 365-375.

Wang, Y. ve Griskevicius, V. (2014). Conspicuous consumption, relationships, and rivals: Women's luxury products as signals to other women. Journal of Consumer Research, 40(5), 834-854.

Ward, S. ve Wackman, D. (1971). Family and media influences on adolescent consumer learning. American Behavioral Scientists, 14(January/February), 415-427.

Zahavi, A. ve Zahavi, A. (1997). The handicap principle: A missing piece of darwin's puzzle. New York: Oxford University Press.

Znidersic, R.K., Salai, S., Grubor, A. ve Maric, D. (2013). Ethical consumer behavior in marketing. International Journal of Multidisciplinary in Business and Science, 1(1), 52-60.

EK 1. Ölçeklerin Açımlayıcı Faktör Analizi Sonuçları

\begin{tabular}{|c|c|c|}
\hline Gösterişçi Tüketim Eğilimi Ölçeği & $\begin{array}{c}\text { Faktör } \\
1\end{array}$ & $\begin{array}{l}\text { Faktör } \\
2\end{array}$ \\
\hline Ürün alırken prestij, benim için önemli bir faktördür. &, 642 &, 250 \\
\hline $\begin{array}{l}\text { Bir ürünün diğer insanların ilgisini çekme özelliği, satın alma } \\
\text { kararı vermemde önemli bir unsurdur. }\end{array}$ & ,623 & ,417 \\
\hline $\begin{array}{l}\text { Ürün hakkında diğer insanların ne düşündükleri, satın alma } \\
\text { kararı vermemde önemlidir. }\end{array}$ & ,381 & ,496 \\
\hline Gösteriş amaçlı ürün satın alan insanlara karşı değilim. & ,564 &,- 079 \\
\hline $\begin{array}{l}\text { Hemen hemen tüm insanların, dikkat çekmek için ürün satın } \\
\text { alma eğiliminde olduklarını düşünüyorum. }\end{array}$ &,- 149 & ,750 \\
\hline $\begin{array}{l}\text { Daha prestijli bir ürün almak için extra para ödemekten } \\
\text { çekinmiyorum. }\end{array}$ & ,729 &,- 064 \\
\hline
\end{tabular}




\begin{tabular}{|c|c|c|c|}
\hline İnsanlar birbirlerini sahip olduklarıyla yargılamaktadır. &,- 066 & ,649 & \\
\hline $\begin{array}{l}\text { Diğer insanlar üzerinde etki yaratmayı gizlice umarak bir } \\
\text { şeyler satın alıyorum. }\end{array}$ & ,410 & ,539 & \\
\hline $\begin{array}{l}\text { Kullandığım ürünlere ve markalara göre insanların beni } \\
\text { yarg1ladıklarını düşünüyorum. }\end{array}$ & ,310 & 479 & \\
\hline Toplam Açıklanan Varyans & \multicolumn{2}{|c|}{$\% 45,361$} & $\begin{array}{l}\text { KMO:,749 } \\
\text { Sig.: ,000 }\end{array}$ \\
\hline Ahlaki Tüketim Eğilimi Ölçeği & $\begin{array}{c}\text { Faktör } \\
1\end{array}$ & $\begin{array}{l}\text { Faktör } \\
2\end{array}$ & $\begin{array}{c}\text { Faktör } \\
3\end{array}$ \\
\hline Bir markette parasını ödemeden bir şey alıp içmek &, 088 &, 068 &, 743 \\
\hline $\begin{array}{l}\text { Başkasının internet ağına (wireless) ondan izinsiz bir şekilde } \\
\text { bağlanarak internete girmek }\end{array}$ & ,129 & 455 & ,537 \\
\hline $\begin{array}{l}\text { Sigorta şirketinden para alabilmek için aslında kayıp olan bir } \\
\text { eşyayı çalınmış gibi göstermek }\end{array}$ & ,414 &,- 017 & ,710 \\
\hline $\begin{array}{l}\text { Hesap olması gerekenden daha az geldiğinde bunu } \\
\text { çaktırmamak }\end{array}$ & ,302 & ,537 & ,293 \\
\hline $\begin{array}{l}\text { Fiyat indirimlerinden yararlanmak için yaşını olduğundan } \\
\text { küçük göstermek }\end{array}$ & ,695 & ,222 & ,333 \\
\hline Satın almadığın bir ürünün indirim kuponunu kullanmak & ,807 & ,169 & ,216 \\
\hline Son kullanım tarihi geçmiş indirim kuponu kullanmak & ,787 & ,288 & 139 \\
\hline Sinemada film izlerken gizli bir şekilde filmi kaydetmek & 034 & ,473 & ,483 \\
\hline $\begin{array}{l}\text { Bir ürünü satın alıp kullandıktan sonra o ürünü beğenmeyip } \\
\text { geri iade etmek }\end{array}$ & ,610 & ,389 & ,018 \\
\hline Bir albümü satın almak yerine internetten indirmek & 185 & ,820 &, 078 \\
\hline $\begin{array}{l}\text { Bilgisayar yazılımlarını satın almadan korsanlarını indirip } \\
\text { kullanmak }\end{array}$ & ,372 & ,758 & ,118 \\
\hline $\begin{array}{l}\text { Bir mağazada bir sürü farklı kıyafet deneyip hiçbirini satın } \\
\text { almadan çıkmak }\end{array}$ & ,416 & ,565 & ,019 \\
\hline Toplam Açıklanan Varyans & \multicolumn{2}{|c|}{$\% 60,204$} & $\begin{array}{l}\text { KMO:,867 } \\
\text { Sig.: ,000 }\end{array}$ \\
\hline Materyalist Eğilimler Ölçeği & $\begin{array}{l}\text { Faktör } \\
1\end{array}$ & $\begin{array}{l}\text { Faktör } \\
2\end{array}$ & $\begin{array}{l}\text { Faktör } \\
3\end{array}$ \\
\hline Pahalı evi, arabası veya kıyafetleri olan insanlara imreniyorum. &, 142 &, 841 &, 015 \\
\hline $\begin{array}{l}\text { Hayattaki en önemli başarılardan biri sahip olunan maddi } \\
\text { varlıklardır. }\end{array}$ & , 149 & ,437 & ,630 \\
\hline $\begin{array}{l}\text { Sahip olduklarım, hayatımın nasıl olduğu hakkında çok şey } \\
\text { söyler. }\end{array}$ & ,126 &,- 069 & ,784 \\
\hline İnsanları hayran bırakan şeylere sahip olmak istiyorum. &,- 058 & ,629 & ,394 \\
\hline Çok pratik olmayan şeylere para harcamak hoşuma gidiyor. & ,155 & ,374 &,- 209 \\
\hline $\begin{array}{l}\text { Şu an sahip olmadığım bazı şeylere sahip olsaydım hayatım } \\
\text { daha iyi olurdu. }\end{array}$ & ,807 &,- 055 & ,097 \\
\hline Daha çok şey satın alma gücüm olsaydı daha mutlu olurdum. & ,798 & ,072 & ,279 \\
\hline İstediğim her şeyi alamıyor olmak bazen canımı sıkıyor. & ,684 & ,324 &,- 076 \\
\hline Toplam Açıklanan Varyans & \multicolumn{2}{|c|}{$\% 64,502$} & $\begin{array}{l}\text { KMO: ,697 } \\
\text { Sig.: ,000 }\end{array}$ \\
\hline
\end{tabular}

